Prawo Kanoniczne

$55(2012) \mathrm{nr} 4$

O. DARIUSZ BOREK O.CARM.

Uniwersytet Kardynała Stefana Wyszyńskiego w Warszawie

\title{
PRZESTĘPSTWA PRZECIWKO SAKRAMENTOM W NORMACH DE DELICTIS RESERVATIS Z 2010 ROKU
}

Treść: Wstęp. - 1. Przestępstwa przeciwko świętości najczcigodniejszej Ofiary i sakramentu Eucharystii. - 1.1. Profanacja postaci konsekrowanych.-1.2. Usiłowanie czynności liturgicznej Ofiary Eucharystycznej. - 1.3. Symulowanie czynności liturgicznej Ofiary Eucharystycznej. - 1.4. Koncelebrowanie Ofiary Eucharystycznej z szafarzami wspólnot kościelnych, które nie posiadają sukcesji apostolskiej oraz nie uznają sakramentalności święceń kapłańskich. - 1.5. Konsekracja, in sacrilegum finem, jednej postaci lub obydwu w czasie Eucharystycznej celebracji lub też poza nią. - 2. Przestępstwa przeciwko świętości sakramentu pokuty. -2.1 . Rozgrzeszenie wspólnika w grzechu przeciwko szóstemu przykazaniu Dekalogu. - 2.2. Usiłowanie rozgrzeszenia sakramentalnego lub zakazane słuchanie spowiedzi. - 2.3. Symulowanie rozgrzeszenia sakramentalnego. - 2.4. Sollicitatio ad turpia, jeżeli ma na celu grzech z samym spowiednikiem. - 2.5. Bezpośrednia i pośrednia zdrada tajemnicy sakramentalnej. - 2.6. Nagrywanie przy pomocy jakiegokolwiek instrumentu technicznego, lub rozpowszechnianie za pomocą środków społecznego przekazu, dokonane ze złośliwością tego, co jest mówione przez spowiednika lub penitenta podczas spowiedzi sakramentalnej, prawdziwej lub fałszywej. - 3. Przestępstwo przeciwko święceniom kapłańskim. - 3.1. Usiłowanie udzielenia święceń kapłańskich kobiecie. - Zakończenie.

\section{Wstęp}

Papież Jan Paweł II Listem Apostolskim Motu Proprio: Sacramentorum sanctitatis tutela z 30 kwietnia 2001 roku promulgował normy o najcięższych przestępstwach zarezerwowanych Kongregacji Nauki Wiary. Takiej interwencji ze strony Kościoła, jak wyjaśniał Papież, domagała się konieczność troski o ochronę świętości sakramentów, szczególnie zaś Eucharystii i Pokuty, jak również konieczność troski o czystość obyczajów w tym, co się odnosi do zachowania szó- 
stego przykazania Dekalogu. Kościół, kierując się duszpasterską troską, szczególnie mając na uwadze cel ostateczny wszelkiego prawa w Kościele, którym winno być salus animarum, interweniował zatem, aby zapobiec niebezpieczeństwom naruszeń w tak ważnej i delikatnej materii, jaką są sakramenty i obyczaje ${ }^{1}$. Kongregacja Nauki Wiary w dniu 18 maja 2001 roku wystosowała list skierowany do Biskupów oraz innych Ordynariuszy i Hierarchów całego Kościoła Katolickiego, w którym powiadamiała o nowych przestępstwach zarezerwowanych Kongregacji, jak również informowała o tym, jak wyżej wspomniani powinni się zachować w przypadku zaistnienia któregoś z wymienionych przestępstw ${ }^{2}$. Po dziewięciu latach od promulgacji Norm $D e$ gravioribus delictis z 2001 roku, Kongregacja Nauki Wiary uznała za konieczne zmodyfikowanie tychże norm, biorąc pod uwagę potrzebę ich zintegrowania i zaktualizowania w celu uproszczenia procedur tak, aby stanowiły jeszcze skuteczniejszą odpowiedź na współczesne problemy ${ }^{3}$. Zmodyfikowane normy dotyczące przestępstw zarezerwo-

1 Joannes Paulus II, Litterae Apostolicae motu proprio datae quibus Normae de gravioribus delictis Congregationi pro Doctrina Fidei reservatis promulgantur, Sacramentorum sanctitatis tutela, 30 aprilis 2001, AAS 93 (2001), s. 737-739. Od tej pory w odniesieniu do Norm z 2001 będzie używane sformułowanie Normy De gravioribus delictis.

2 Congregatio pro Doctrina Fidei, Epistula a Congregatione pro Doctrina Fidei missa ad totius Catholicae Ecclesiae Episcopos aliosquae Ordinarios et Hierarchos interesse habentes: de delictis gravioribus eidem Congregationi pro Doctrina Fidei reservatis, 18 maii 2001, AAS 93 (2001), s. 785-788. Zob. tłumaczenie polskie Listu Kongregacji Doktryny Wiary, Miesięcznik Pasterski Płocki 68 (2001) nr 10, s. 415-417.

${ }^{3}$ Congregazione Per la Dottrina della Fede, Lettera ai Vescovi della Chiesa cattolica e agli altri Ordinari e Gerarchi interessati circa le modifiche introdotte nella Lettera apostolica Motu Proprio data Sacramentorum sanctitatis tutela, 21 maggio 2010, AAS 102 (2010), s. 431; Congregazione per la Dottrina della Fede, Modificate le norme ,, de gravioribus delictis ": procedure più efficaci per contribuire alla chiarezza del diritto, L'Osservatore Romano, 16 lulgio 2010, 1, 4-5, 8. Zob. także Z. Suchecki, Le privazioni e le proibizioni nel Codice di Diritto Canonico del 1983, Città del Vaticano 2010, s. 257-260. W modyfikacjach z 2010 roku zostały uwzględnione zmiany jakie wprowadzono do Norm De gravioribus delictis w latach 2002 i 2003, zarówno w odniesieniu do norm substancjalnych, jak i do norm porcesowych, por. D. CiTo, $L a$ probità morale nel sacerdozio ministeriale (il m.p. "sacramentorum sanctitatis tutela”), Fidedlium Iura 13 (2003), s. 128-133. 
wanych Kongregacji Nauki Wiary zostały przedstawione Papieżowi Benedyktowi XVI, który w dniu 21 maja 2010 roku zatwierdził nowe normy, nakazując ich promulgowanie ${ }^{4}$. Na Normy De delictis reservatis z 2010 roku składają się dwie części: cześć pierwsza to Normae substantiales obejmująca art. 1-7, cześć druga to Normae processuales obejmująca art. 8-31. W części pierwszej zostały zawarte dyspozycje dotyczące zakresu kompetencji Kongregacji Nauki Wiary, następnie zostały szczegółowo wyliczone poszczególne przestępstwa należące do kategorii delicta reservata, oraz zostały podane dyspozycje dotyczące przedawnienia actio criminalis w przypadku delicta reservata. Natomiast druga część, to szereg szczegółowych dyspozycji dotyczących sposobu postępowania w przypadku delicta reservata, w odniesieniu do których Kongregacja Nauki Wiary jest Najwyższym Trybunałem Apostolskim 5 . W obecnym artykule analizie zostaną poddane jedynie te spośród przestępstw zarezerwowanych aktualnie Kongregacji Nauki Wiary, które dotyczą sakramentów Eucharystii, pokuty i święceń kapłańskich6 ${ }^{6}$.

${ }^{4}$ Congregatio pro Doctrina Fidei, Normae de delictis Congregationi pro Doctrina Fidei reservatis seu Normae de delictis contra fidem necnon de gravioribus delictis (21.05.210), AAS 102 (2010), s. 419-434. Od tej pory w odniesieniu do Norm z 2010 roku bedzie się używać sformułowania Normy De delictis reservatis.

${ }^{5}$ Szerzej na temat norm procesowych dotyczących przestępstw zarezerwowanych Kongregacji Nauki Wiary zob. CH. J. SciclunA, Delicta graviora ius processuale, w: Questioni attuali di diritto penale canonico, Studi Giuridici 96 Città del Vaticano 2012, s. 79-94; C. PAPAle, Formulario commentato del processo penale canonico, Città del Vaticano 2012, s. 177-252; V. MARIA SABATANI, I graviora delicta riservati alla Congregazione per la Dottrina della Fede, Roma 2011; D. Cіто, Nota alle nuove norme su "delicta graviora", Ius Ecclesiae 22 (2010), s. 787-799.

${ }^{6}$ Normy De gravioribus delictis z 2001 roku do kategorii delicta graviora zaliczały przęstepstwa przeciwko sakramentom Eucharystii i pokuty, CONGREGATIO PRo DoctrINA FIDEI, Epistula..., s. 785-786. Zob także D. BoreK, Ordynariusz a $<$ Delicta Graviora> zarezerwowane Kongregacji Doktryny Wiary, Prawo Kanoniczne 47 (2004) 3-4, s. 99-128. Na temat wszystkich modyfikacji wprowadzonych w materii delicta graviora zob. M. StokŁosa, Modyfikacje wprowadzone do tekstu Normae de gravioribus delictis, Prawo i Kościół 3 (2011), s. 101-129. 


\section{Przestępstwa przeciwko świętości najczcigodniejszej Ofiary i sakramentu Eucharystii}

Mając na uwadze ochronę świętości najświętszej Eucharystii, Normy De delictis reservatis z 2010 roku rezerwują Kongregacji Nauki Wiary pięć przestępstw contra sanctitatem augustissimi Eucharistiae Sacrificii et Sacramento, a mianowicie przestępstwa: profanacji postaci konsekrowanych; usiłowania czynności liturgicznej Ofiary Eucharystycznej; symulowania czynności liturgicznej Ofiary Eucharystycznej; koncelebrowania Ofiary Eucharystycznej z szafarzami wspólnot kościelnych, które nie posiadają sukcesji apostolskiej oraz nie uznają sakramentalności święceń kapłańskich; konsekracji in sacrilegum finem, jednej postaci lub obydwu w czasie Eucharystycznej celebracji lub też poza nią ${ }^{7}$. Cztery pierwsze spośród wyliczonych przestępstw są obwarowane sankcjami karnymi w KPK/1983 oraz w KKKW/1990. Wspomniane Kodeksy nie posiadają analogicznej normy w odniesieniu do ostatniego z przestępstw. W porównaniu z Normami z 2001 roku, w zakresie przestępstw przeciwko Eucharystii, nastąpiły pewne zmiany zarówno co do liczby, jak i sposobu sformułowania niektórych przestępstw, ale nie są to zmiany o charakterze innowacyjnym ${ }^{8}$. Zmiany wprowadzone w Normach z 2010 roku polegaja jedynie na lepszym, jak się wydaje bardziej precyzyjnym, sformułowaniu niektórych z przestępstw. Faktycznie aktualne normy rozważają oddzielnie przestępstwo polegające na usiłowaniu czynności liturgicznej Ofiary Eucharystycznej i oddzielnie przestępstwo symulowania tejże czynności. Podczas gdy Normy z 2001 roku ujmowały je razem. Kolejna zmiana dotyczy przestępstwa konsekracji postaci konsekrowanych in sacrilegum fine. Aktualne sformułowanie, consecratione in sacrilegum finem unius materiae vel utriusque in eucharistica celebratione, aut extra eam, wydaje się być bardzie precyzyjne, przez co unika się trud-

7 Congregatio Pro Doctrina Fidei, Normae de delictis Congregationi pro Doctrina Fidei reservatis..., s. 421-422.

8 Por. Congregatio pro Doctrina Fidei, Epistula..., s. 786. Zob. V. De Paolis, Norme de gravioribus delictis riservati alla Congregazione per la Dottrina della Fede, Periodica 91 (2002), s. 300-304. 
ności interpretacyjnych, jakie mogły powstawać w związku z wykładnią analogicznego sformułowania w Normach z 2001.

W materii karania za przestępstwa przeciwko świętości najczcigodniejszej Ofiary i sakramentu Eucharystii zachowują moc dyspozycje zawarte w kanonach zajmujących się poszczególnymi przestępstwami. W odniesieniu natomiast do przestępstwa polegającego na konsekracji in sacrilegum finem, jednej postaci lub obydwu w czasie Eucharystycznej celebracji lub też poza nią, Normy z 2010 roku przewidują obowiązkowy wymiar kar ferendae sententiae, zarówno w postaci nieokreślonej, do wymierzenia według ciężkości przestępstwa, jak i w formie kary określonej w postaci dymisji lub depozycji ${ }^{9}$.

\subsection{Profanacja postaci konsekrowanych}

Pierwsze spośród przestępstw dotyczących Eucharystii, które zostały zarezerwowane Kongregacji Nauki Wiary w Normach De delictis reservatis z 2010 roku, to przestępstwo profanacji postaci konsekrowanych, polegające na: zabieraniu (abductio), przechowywaniu (retentio) oraz porzucaniu (abiectio) postaci konsekrowanych ${ }^{10}$. Analogiczną dyspozycję w tej materii zawiera zarówno Kodeks Prawa Kanonicznego z 1983 roku$^{11}$ oraz Kodeks Kanonów Kościołów Wschodnich z 1990 roku $^{12}$, jak i Normy De gravioribus delictis z 2001 roku $^{13}$.

Zabiera postacie konsekrowane ten, kto wyciaga je z miejsca, gdzie normalnie się znajduja, czy są przechowywane i zanosi je do inne-

9 Art. 3: "§ 2 Qui hoc delictum patraverit, pro gravitate criminis puniatur, non exclusa dimissione vel depositione", CONGREGATIO PRo Doctrina FideI, Normae de delictis Congregationi pro Doctrina Fidei reservatis..., s. 422.

${ }^{10}$ Art. 3: " $\$ 1$, n. $1^{\circ}$ abductio vel retentio in sacrilegum finem, aut abiectio consecratarum specierum, de quibus in can. 1367 Codicis Iuris Canonici et in can. 1442 Codicis Canonum Ecclesiarum Orientalium", Congregatio Pro Doctrina Fidei, Normae de delictis Congregationi pro Doctrina Fidei reservatis ..., s. 421.

${ }^{11} \mathrm{KPK} / 1983$, kan. 1367.

${ }^{12}$ KKKW/1990, kan. 1442.

${ }^{13}$ Por. Congregatio Pro Doctrina Fidei, Epistula..., s. 786. Zob. G. NúÑEz, La competencia penal de la Congregación para la Doctrina de la Fe. Comentario al m.p. Sacramentorum Sanctitatis Tutela, Ius Canonicum 53 (2003), s. 371-372; D. BoreK, Ordynariusz a $<$ Delicta Graviora $>$..., s. 100-105. 
go miejsca, nieprzystosowanego do tego celu, chociaż nie byłoby to miejsce brudne lub niewłaściwe. Takiemu działaniu, aby mogło zostać uznane za przestępstwo, musi jednak towarzyszyć specyficzny cel. Normy De delictis reservatis wyraźnie postanawiają, że owa abductio musi być dokonana in sacrilegum finem. Istota omawianej formy przestępstwa polega, zatem nie tyle na wyniesieniu postaci konsekrowanych z miejsca, w którym zgodnie z prawem są przechowywane, ale właśnie na zamiarze znieważenia tychże postaci ${ }^{14}$. Cel jest świętokradczy, kiedy postacie konsekrowane są przeznaczone do tego, aby być przedmiotem aktów bezwstydnych i bezbożnych, do celebracji czarnych mszy, rytów satanistycznych lub masońskich, magii, wróżbiarstwa lub innego rodzaju zabobonów ${ }^{15}$. Cel świętokradczy należy domniemywać wtedy, kiedy osoba po otrzymaniu postaci konsekrowanych, symulując na przykład chęć przyjęcia Komunii Świętej, wyciaga je z ust i je zachowuje, a następnie wrzuca je do śmietniska lub na inne miejsce brudne, nieczyste lub na ziemię albo też do ognia lub wody ${ }^{16}$. Nie popełnia natomiast przestępstwa ten, kto po przyjęciu Komunii św. w dobrej intencji, następnie wyciaga $z$ ust hostię i dla pobożności zachowuje ją w książeczce do nabożeństwa, chociaż z pewnością popełnia grzech ciężki, takie działanie jest bowiem wyraźnie zabronione przez prawo ${ }^{17}$. Z pewnością nie popełnia również przestępstwa świecki, który zabiera postacie konsekrowane, aby nie uległy spaleniu w pożarze, albo, aby nie uległy profanacji. Brakuje tutaj tego celu świętokradczego, a wręcz przeciwnie, jest to czyn godny pochwały. Tym bardziej brakuje jakiegokolwiek czynu świętokradczego, gdy dokonuje tego wszystkiego kapłan, diakon lub jakaś inna osoba upoważniona do udzielania Komunii. Jeżeli chodzi o kapłanów i diakonów, to czynności wyżej wymienione są ich obowiązkiem ${ }^{18}$.

${ }^{14}$ Por. J. SyryjczyK, Kanoniczne prawo karne, część szczególna, Warszawa 2003, S. 50 .

${ }^{15}$ Por. D. Ciтo, Delicta graviora contro la fede e sacramenti, w: Questioni attuali di diritto penale canonico, Studi Giuridici XCVI Città del Vaticano 2012, s. 40.

16 A. Calabrese, Diritto penale canonico, Città del Vaticano 1996, s. 272-273.

${ }^{17}$ KPK/1983, kan. 935.

${ }^{18}$ Por. R. BotTA, La norma penale nel diritto della Chiesa, Bologna 2001, s. 178-179. 
W tym, co się odnosi do przechowywania postaci konsekrowanych należy przypomnieć, że Kongregacja Kultu Bożego i Dyscypliny Sakramentów Instrukcją z 25 marca 2004 roku przypomniała o nakazie przechowywania Najświętszego Sakramentu w tabernakulum, z zachowaniem wszystkich przepisów ksiag liturgicznych i norm prawa, ze względu na konieczność uniknięcia niebezpieczeństwa profanacji. W związku z tym zabrania się przechowywania Najświętszego Sakramentu w miejscu zagrożonym profanacją ${ }^{19}$. Możemy powiedzieć, że przechowuje postacie konsekrowane w miejscu zagrożonym profanacją ten, kto je zachowuje przy sobie, na przykład w kieszeni, w torebce lub w domu, lub też w innym miejscu. Należy jednak zaznaczyć, że do zaistnienia omawianej formy przestępstwa konieczne jest, aby przechowywanie postaci konsekrowanych było dokonywane w celach świętokradczych. Normy De delictis resevatis także i w tym przypadku wyraźnie wymagaja, aby owa retentio była dokonywana in sacrilegum finem. Nie każde więc przechowywanie postaci konsekrowanych poza miejscem do tego przeznaczonym będzie stanowiło przestępstwo profanacji postaci konsekrowanych. Kapłan, który, na przykład, nosi ze sobą bursę z postaciami konsekrowanymi, również wtedy, kiedy idzie ulicą lub znajduje się w autobusie albo po prostu w podróży, aby być zawsze gotowym do udzielenia Wiatyku w razie konieczności, z pewnością nie przetrzymuje postaci konsekrowanych w celach świętokradczych, a zatem nie popełnia przestępstwa, chociaż coś takiego w przypadkach duszpasterskich, które nie są pilne, jest zabronione przez KPK/1983 w kan. 935. Podobnie nie popełnia przestępstwa osoba, która przechowuje postacie konsekrowane w swoim mieszkaniu kierując się źle pojętą pobożnością ${ }^{20}$.

Przestępstwo przechowywania postaci konsekrowanych wiąże się ściśle z omówionym powyżej przestępstwem zabrania tychże postaci. Otóż sprawcą przestępstwa zaboru i przechowywania postaci konse-

\footnotetext{
${ }^{19}$ Kongregacja Kultu Bożego i Dyscypliny Sakramentów, Instrukcja, O zachowaniu i unikaniu pewnych rzeczy dotyczacych Najświętszej Eucharystii, nn. 130-131, Kraków 2004, s. 71-72.

${ }^{20}$ Por. A. Calabrese, Diritto penale..., s. 273.
} 
krowanych może być jedna i ta sama osoba, np. ten, kto zabrał postacie konsekrowane, na przykład przyjmując Komunię św., ale jej nie spożywając i przechuje ją in sacrilegum finem. W tym miejscu pojawia się pytanie, czy osoba, która zabrała postacie konsekrowane i jednocześnie je przetrzymuje w celu świętokradczym popełnia dwa przestępstwa, czy też tylko jedno. Prawdopodobnie ten, kto zabiera i przechowuje postacie konsekrowane popełnia jedno przestępstwo, ponieważ te dwie czynności mogą być uważane za jedna, w zabieraniu Eucharystii mieści się bowiem jej przetrzymywanie, chociaż przechowywanie może oczywiście trwać dłuższy okres czasu. Jak zauważa J. Syryjczyk, intencją prawodawcy jest tutaj podkreślenie karalności różnych podmiotów przestępstwa, bo faktycznie kto inny może dokonać zabrania postaci konsekrowanych, a kto inny je przetrzymywać ${ }^{21}$. W praktyce można przyjąć, że w przypadku zabierania i przechowywania postaci konsekrowanych przez jedną i tę samą osobę, należy mówić raczej o jednym przestępstwie, chociaż o większym ciężarze ${ }^{22}$.

Ostatnia $\mathrm{z}$ form profanacji postaci konsekrowanych to porzucanie tychże postaci. Porzucanie (łac. abiectio od abicere - porzucać), o którym mowa, powinno być rozumiane w bardzo szerokim znaczeniu. Zgodnie bowiem z intencją Papieskiej Rady ds. Interpretacji Tekstów Ustaw używane tutaj słowo abicit oznacza ,quamlibet actionem Sacras Species voluntarie et graviter despicientem", a więc jakiekolwiek dobrowolne i dokonane z wielką pogardą działanie wobec postaci konsekrowanych $^{23}$. Przez porzucanie postaci konsekrowanych należy zatem rozumieć ich rzucanie lub rozrzucanie po ziemi, do ognia, na wysypisko śmieci, do latryny lub do innego miejsca brudnego z powodu pogardy, braku szacunku, ze złośliwości, z powodu nienawiści do Boga oraz z jakiegokolwiek innego powodu. Porzucaniem będzie także dep-

${ }^{21}$ J. SyryJCZYK, Profanacja Eucharystii wedtug karnego ustawodawstwa kanonicznego i polskiego prawa karnego, Prawo Kanoniczne 29 (1986) nr 3-4, s. 197-198.

${ }^{22}$ Por. A. Calabrese, Diritto penale..., s. 274; B. F. Pighin, Diritto penale canonico, Venezia 2008, s. 335-336; J. SYRYJCZYK, Kanoniczne prawo karne..., s. 50-51; G. URRU, Punire per salvare. Il sistema penale nella chiesa, Roma 2002, s. 198.

${ }^{23}$ Por. Pontificium Consilium de Legum Textibus Interpretandis, Responsio ad propositum dubium, 4 iunii 1999, Communicationes 31/1 (1999), s. 38. 
tanie tychże postaci, wypluwanie z ust po otrzymaniu Komunii św. lub opluwanie, albo też rzucanie na nie nawozu lub zanieczyszczeń, strzelanie do nich ${ }^{24}$. Ponadto w sformułowaniu ,quamlibet actionem Sacras Species voluntarie et graviter despicientem", należałoby uwzględniać także i te sytuacje, kiedy Najświętszy Sakrament wystawiony do adoracji będzie przedmiotem obelg oraz zniewagi ${ }^{25}$. Jest oczywiste, że we wszystkich powyższych działaniach należy domniemywać złośliwość i świętokradztwo. Nie popełnia natomiast przestępstwa złodziej puszki, w której przechowywane są postacie konsekrowane, który składa najpierw hostie konsekrowane na ołtarzu lub wewnątrz tabernakulum, a więc w miejscach, które są konsekrowane i właściwe, jeżeli chodzi o deponowanie postaci konsekrowanych. Popełni jednak przestępstwo profanacji złodziej, który kradnąc wartościowy kielich, rozlewa po ziemi lub w innym miejscu nieodpowiednim wino konsekrowane. Nie popełnia natomiast przestępstwa, jeżeli przelewa wino konsekrowane do innego pojemnika, na przykład do szklanki i kładzie ją na ołtarzu ${ }^{26}$.

Podsumowując należy zaznaczyć, że o przestępstwie profanacji postaci konsekrowanych będzie można mówić dopiero wtedy, kiedy podjęte czynności, czy to zabierania, czy przechowywania, czy też porzucania, będą dotyczyć postaci konsekrowanych, bo tylko w nich wiara katolicka dostrzega rzeczywistą, prawdziwą i substancjalną obecność

${ }^{24}$ Wymienione działania, w myśl ścisłej interpretacji słowa porzucać, nie mogły być do roku 1999 podciągane pod pojęcie przestępstwa profanacji Najświętszego Sakramentu, a jedynie mogły zostać kwalifikowane jako przestępstwa profanacji w myśl kan. 1376 KPK/1983, por. J. SYRYJCZYK, Kanoniczne prawo karne..., s. 49.

${ }^{25}$ Pontificium Consilium de Legum Textibus Interpretandis, Tutela della Sanctissima Eucaristia, Communicationes 31/1 (1999), s. 40. Zob. także D. Ciтo, Delicta graviora..., s. 40.

${ }^{26}$ Przypadek rozlania wina konsekrowanego jest raczej przypadkiem hipotetycznym, ponieważ wino konsekrowane jest spożywane podczas Ofiary Eucharystycznej, podczas której zostało konsekrowane i dlatego też jest tutaj raczej mało prawdopodobne jakieś wykroczenie. Mogłoby się jednakże wydarzyć, że na przykład jakiś kapłan koncelebrujący podczas Mszy św., lub jakiś świecki w celebracjach, w których otrzymują kielich z krwią Pańską również świeccy, pijąc krew następnie ją rozpryskuje na ziemię. 
Ciała i Krwi Jezusa Chrystusa ${ }^{27}$. Aby stwierdzić, że postacie są konsekrowane wystarczy, że znajdują się w tabernakulum, lub że są adorowane przez wiernych, albo rozdawane im. Kto natomiast dokonuje profanacji postaci jeszcze nie konsekrowanych wierząc, że są konsekrowane, popełnia grzech, ale nie przestępstwo. Przedmiotem profanacji mogą być jednocześnie obydwie postacie, a więc chleb i wino, ale należy pamiętać, że z przestępstwem będziemy mieli do czynienia również i wtedy, kiedy profanacji ulegnie tylko jedna $\mathrm{z}$ tych posta$\mathrm{ci}^{28}$. Ponadto należy zwrócić uwagę na fakt, że chociaż tylko w dwóch pierwszych przypadkach wyraźnie się mówi o celu świętokradczym takiego działania - in sacrilegum finem, to jednak taka celowość działania musi być obecna także i w trzeciej z form, czyli w porzucaniu. Tak więc do istotnych znamion omawianego przestępstwa należy zaliczyć cel świętokradczy takiego działania, i to niezależnie od tego, czy faktycznie dojdzie do sprofanowania postaci konsekrowanych ${ }^{29}$.

\subsection{Usiłowanie czynności liturgicznej Ofiary Eucharystycznej}

Drugie z przestępstw przeciwko Najświętszej Eucharystii, jakie zostało zarezerwowane Kongregacji Nauki Wiary w Normach De delictis reservatis z 2010 roku, to usiłowanie czynności liturgicznej Ofiary Eucharystycznej ${ }^{30}$. Usiłowanie czynności liturgicznej Ofiary Eucharystycznej jest uznane za przestępstwo w Kodeksie Prawa Kanoniczne-

${ }^{27}$ Do zaistnienia przestępstwa nie jest konieczne, aby taka wiara istniała po stronie osoby je popełniającej. Wystarczy, aby sprawca wiedział, że ma do czynienia z postaciami konsekrowanymi, albo jeszcze lepiej, aby wiedział, jaka jest wiara Kościoła w tej materii. Oczywiście niezależnie od tego, czy sprawca jest wierzący, czy też nie, musi jednak spełniać kryteria podlegania usatwom czysto - kościelnym (kann. 1 i 11), por. D. Ciтo, Delicta graviora..., s. 40.

${ }^{28}$ Por. tamże, s. 39.

${ }^{29}$ Por. A. D‘Auria, L imputabilità nel diritto penale canonico, Roma 1997, s. 87-88. Zob. także: J. SyryjCzyK, Kanoniczne prawo karne..., s, 51; tenże, Sankcje w Kościele. Część ogólna, komentarz, Warszawa 2008, s. 115.

${ }^{30}$ Art. 3: " $\$ 1$, n. $2^{\circ}$ attentatio liturgicae eucharistici Sacrificii actionis, de qua in can. $1378 \S 2$ n. 1 Codicis Iuris Canonici”, Congregatio pro Doctrina Fidei, Normae de delictis Congregationi pro Doctrina Fidei reservatis..., s. 421. 
go z 1983 roku $^{31}$, brakuje natomiast analogicznej normy w Kodeksie Kanonów Kościołów Wschodnich z 1990 roku². Normy De gravioribus delictis z 2001 roku omawianą formą przestępstwa ujmowały łącznie z przestępstwem symulowania czynności liturgicznej Ofiary Eucharystycznej ${ }^{33}$. Jedyna zmiana, jaka została wprowadzona przez nowe normy $\mathrm{w}$ materii omawanego przestępstwa, polega na ujęciu w oddzielne paragrafy przestępstwa usiłowania (o którym w kan. 1378 $\S 2$, n. 1 KPK/1983) i przestępstwa symulownia (o którym w kan. 1379 KPK/1983 i w kan. 1443 KKKW/1990). W myśl obowiązującego prawa jest działaniem niedozwolonym, i zarazem karalnym sprawowanie czynności liturgicznej Ofiary Eucharystycznej przez osobę do tego niezdolną. Do zaistnienia przestępstwa w omawianym przypadku konieczne są następujące elementy: po pierwsze - faktyczne wykonanie czynności liturgicznej Ofiary Eucharystycznej; po drugie - brak wymaganej zdolności ze strony osoby wykonującej powyższą czynność.

Co do pierwszego warunku przestępstwa należy zaznaczyć, że przedmiotem usiłowania jest czynność liturgiczna Ofiary Eucharystycznej. W sensie ścisłym czynność liturgiczna Ofiary Eucharystycznej oznacza tę część Mszy św., która ma miejsce od prefacji do Ojcze $\mathrm{Nasz}^{34}$. Mając na uwadze zasadę ścisłej interpretacji ustaw karnych (kan. 18), do zaistnienia przestępstwa nie należałoby wymagać, aby została odprawiona cała Msza św., lecz przynajmniej jej część istotna, to znaczy Modlitwa Eucharystyczna ${ }^{35}$. Za taką interpretacją przema-

${ }^{31} \mathrm{KPK} / 1983$, kann. 1378 § 2; 1379.

${ }^{32}$ Jest tutaj jedynie mowa ogólnie o symulacji sakramentów, por. KKKW/1990, kan. 1443.

${ }^{33}$ Congregatio pro Doctrina Fidei, Epistula..., s. 786. Zob. G. NúÑez, La competencia penal..., s. 372-374; D. BoreK, Ordynariusz a $<$ Delicta Graviora $>$..., s. 106110.

${ }^{34}$ Zob. Kongregacja Kultu Bożego i dyscypliny sakramentów, Nowe Ogólne Wprowadzenie do Mszału Rzymskiego, Pallottinum, Poznań 1986, n. 28, 72-89, s. 20, $34-40$.

${ }^{35}$ V. De Paolis - D. Cito, Le sanzioni nella Chiesa. Commento al Codice di Diritto Canonico, Libro VI, Roma 2000, s. 329. Por. także R. BотTA, La norma penale..., s. 204 . 
wia również i to, że w Instrukcji o zachowaniu $i$ unikaniu pewnych rzeczy dotyczacych Najświętszej Eucharystii zostało wyraźnie stwierdzone, że odmawianie Modlitwy Eucharystycznej jest zastrzeżone kapłanowi na mocy jego święceń ${ }^{36}$. W związku z powyższym nie będzie wystarczające dla powstania przestępstwa, o którym mowa, podjęcie przez osobę tylko takich czynności Mszy św., jak wdzianie szat liturgicznych, wyjście do ołtarza, zapowiedzenie liturgii mszalnej, czy też wykonanie innych ceremonii związanych ze Mszą św., jednakże bez podjęcia czynności liturgicznej Ofiary Eucharystycznej ${ }^{37}$. Podsumowując, należy stwierdzić, że omawiane przestępstwo będzie miało miejsce zarówno wtedy, kiedy zostaną w całości wykonane obrzędy Mszy św., jak i wtedy, kiedy zostaną wykonane przynajmniej gesty oraz słowa czynności liturgicznej Ofiary Eucharystycznej. Przestępstwo usiłowania czynności liturgicznej Ofiary Eucharystycznej może mieć bowiem miejsce także w trakcie prawdziwej celebracji, a mianowicie w czasie koncelebry. Przestępstwa dopuszczają się w takim przypadku współkoncelebrujący, nie będący prawdziwymi kapłanami, a wykonujący czynność liturgiczną Ofiary Eucharystycznej ${ }^{38}$.

Co do drugiego warunku, to zgodnie z paragrafem pierwszym kan. 900 KPK/1983, osobą mogącą ważnie sprawować sakrament Eucharystii jest jedynie kapłan ważnie wyświęcony ${ }^{39}$. Wszyscy inni członko-

\footnotetext{
${ }^{36}$ Kongregacja Kultu Bożego i Dyscypliny Sakramentów, Instrukcja, O zachowaniu i unikaniu pewnych rzeczy..., art. 52.

${ }^{37}$ J. Syryjczyk, komentując kan. 1378 § 2, n. 1, stwierdza, że usiłuje odprawić Mszę św. ten kto wykonuje wszystkie czynności liturgii mszalnej, albo tylko niektóre z nich, np. przywdzianie szat liturgicznych, wyjście do ołtarza, zapowiedzenie liturgii. Jak zauważa wspomniany autor, istotny byłby tutaj zamiar wprowadzenia w błąd, a bez znaczenia byłoby natomiast to, czy rzeczywiście były odmówione przepisane modlitwy oraz wypowiedziane słowa konsekracji. Przestępstwo miałoby się dokonać już w momencie rozpoczęcia odprawiania Mszy św., niezależnie od tego, czy została zakończona czy też nie, por. J. SyryJCZyK, Kanoniczne prawo karne..., s. 103-104.

${ }^{38}$ Zob. tamże, s. 104.

${ }^{39}$ Warto w tym miejscu przypomnieć, że, zgodnie z kan. 1024 KPK/1983, ważnie święcenia kapłańskie może przyjąć jedynie mężczyzna ochrzczony. Absolutną niezdolność kobiet do przyjęcia święceń kapłańskich potwierdził Papież Jan Paweł II w Liście Apostolskim Ordinatio sacerdotalis, z 22 maja 1994 roku, gdzie wyraźnie stwierdził, iż Kościół nie posiada takiej władzy, aby kobiety dopuścić do świę-
} 
wie Kościoła, czy to diakoni przygotowujący się do kapłaństwa, czy diakoni permanentni, jak również osoby konsekrowane przez profesję Rad Ewangelicznych, ale nie będące kapłanami, oraz wierni świeccy, są niezdolni, z prawa boskiego, do sprawowania czynności liturgicznej Ofiary Eucharystycznej. Gdyby zatem osoba nie będąca kapłanem sprawowała czynność liturgiczną Ofiary Eucharystycznej, mielibyśmy do czynienia jedynie z usiłowaniem tejże czynności, ponieważ byłaby dokonana przez osobą niezdolną.

Powodów, dla których ktoś może usiłować czynności liturgicznej Ofiary Eucharystycznej może być wiele. Może to być wynik pewnych patologicznych zachowań o charakterze mistycznym, np. sprawuje Mszę św. ktoś, kto jest przekonany o tym, że jest kapłanem. Mogą to być również osoby działające na podstawie opinii, według której do wszystkich ochrzczonych odnosi się polecenie Chrystusa o ustanowieniu i sprawowaniu Eucharystii, albo przykładowo kobiety występujące przeciw nauce Kościoła w kwestii dopuszczania kobiet do święceń kapłańskich ${ }^{40}$. Nie będzie natomiast przestępstwem w omawianym znaczeniu wykonywanie czynności liturgicznej Ofiary Eucharystycznej przez aktora, czy też przez diakona uczącego się odprawiania Mszy przed przyjęciem święceń.

\subsection{Symulowanie czynności liturgicznej Ofiary Eucharystycznej}

Trzecie z przestępstw związanych z Najświętszą Eucharystią, jakie zostało zarezerwowane Kongregacji Nauki Wiary w nowych normach, to symulowanie czynności liturgicznej Ofiary Eucharystycznej ${ }^{41}$. Przestępstwo to jest rozważane zarówno w kan. 1379 Kodeksu Prawa

ceń kapłańskich. JAN PAWEŁ II, List Apostolski, Ordinatio Sacerdotalis, 22 maj 1994, L'Osservatore Romano 8 (1994), s. 7-8. Zob. także SACra Congregatio Pro Doctrina FIDEI, Declaratio, Circa quaestionem admissionis mulierum ad sacerdotium ministeriale Inter insigniores, 15 octobris 1976, AAS 69 (1977), s. 98-116.

${ }^{40}$ Por. D. Ciтo, Delicta graviora..., s. 42.

${ }^{41}$ Art. 3: "§ 1, n. 3 simulatio liturgicae eucharistici Sacrificii actionis, de qua in can. 1379 Codicis Iuris Canonici et in can. 1443 Codicis Canonum Ecclesiarum Orientalium", Congregatio pro Doctrina Fidei, Normae de delictis Congregationi pro Doctrina Fidei reservatis..., s. 421. 
Kanonicznego z 1983 roku ${ }^{42}$, jak i w kan. 1443 Kodeksu Kanonów Kościołów Wschodnich z 1990 roku $^{43}$. Normy De gravioribus delictis z 2001 roku ujmowały to przestępstwo łącznie z przestępstwem usiłowania liturgicznej czynności Ofiary Eucharystycznej ${ }^{44}$.

Cytowane powyżej kanony, mówią o symulowaniu jakiegokolwiek sakramentu: chrztu ${ }^{45}$; bierzmowania ${ }^{46}$; eucharystii; pokuty; namaszczenia chorych ${ }^{47}$; kapłaństwa; małżeństwa ${ }^{48}$. Oczywiście wyłączone są tutaj pozostałe akty kultu, takie jak poświęcenia czy błogosławieństwa $^{49}$. Należy jednak zaznaczyć, że do katalogu przestępstw zarezerwowanych Kongregacji Nauki Wiary została włączona jedynie symulacja czynności liturgicznej Ofiary Eucharystyczne oraz, o czym będzie

${ }^{42} \mathrm{KPK} / 1983$, kan. 1379. Należy także zaznaczyć, że powyższe przestępstwo pociąga za sobą również nieprawidłowość do przyjęcia święceń, od której może dyspensować Ordynariusz (KPK/1983, kann. 1041 n. 6, 1047 § 4).

${ }^{43}$ KKKW/1990, kan. 1443.

${ }^{44}$ Por. Congregatio pro Doctrina Fidei, Epistula..., s. 786. Zob. G. NúÑEz, La competencia penal..., s.. 372-374; D. Borek, Ordynariusz a $<$ Delicta Graviora > ..., s. 106110.

${ }^{45}$ Symulowanie w przypadku sprawowania sakramentu chrztu może mieć miejsce, albo w sytuacji wykluczenia woli czynienia tego co czyni Kościół (kan. 861 §), albo w przypadku użycia płynów innych aniżeli woda (kan. 849), por. B.F. PIghin, Diritto penale..., s. 396.

${ }^{46}$ Symulowanie sakramentu bierzmowania, może mieć miejsce w przypadku świadomego udzielenia bierzmowania przez osobę pozbawioną ipso iure upoważnienia lub specjalnego udzielenia, por. tamże, s. 396.

${ }^{47}$ Symulowanie sakramentu namaszczenia chorych może wystąpić w przypadku udzielenia sakramentu bez należytej intencji, albo przez diakona lub osobę świecką, por. tamże, s. 396.

${ }^{48}$ Symulowanie sakramentu małżeństwa może polegać na symulowaniu zgody małżeńskiej przez jednego lub obydwu nupturientów. Można sobie jednak zadać pytanie, czy rzeczywiście osoba, która pozytywnym aktem woli symuluje zgodę małżeńską, popełnia przestępstwo o którym w kan. 1379. Wydaje się bowiem mało prowadopodobne, aby takie działanie symulacyjne spełniało wymogi winy umyślnej koniecznej do zaistnienia przestępstwa, por. P. BARBERO, Tutela della comunione ecclesiale e sanzioni canoniche, Lugano 2011, s. 154; B. F. Pighin, Diritto penale ..., s. 397. Ponadto trudno przypisać sprastwo tego przestępswta kapłanowi asystującemu przy zawieraniu małżeństwa symulownego, por. A.G. URRU, Punire per salvare..., s. 226.

${ }^{49}$ Por. J. Syry JCZYK, Kanoniczne prawo karne..., s. 107. 
mowa później, symulacja absolucji sakramentalnej i święceń kapłańskich. Do zaistnienia przestępstwa w omawianym obecnie przypadku konieczne są następujące elementy: po pierwsze - faktyczne wykonanie czynności liturgicznej Ofiary Eucharystycznej; po drugie - brak wymaganej intencji po stronie osoby dokonującej takiej czynności.

Co do pierwszego warunku przestępstwa należy zaznaczyć, że ma zastosowanie to, co zostało powiedziane powyżej odnośnie usiłowania czynności liturgicznej Ofiary Eucharystycznej. Natomiast w odniesieniu do drugiego z warunków, należy stwierdzić, że czynność symulacji w ścisłym tego słowa znaczeniu ma miejsce wtedy, kiedy zostały podjęte wszystkie czynności zewnętrzne, które wymagane są na przykład do ważności jakiegoś sakramentu, ale ten pozostaje nieważny ponieważ osoba, pomimo posiadania wymaganej zdolności ${ }^{50}$, nie ma jednak koniecznej intencji, to znaczy wewnętrznym aktem woli wyklucza udzielenie sakramentu ${ }^{51}$. Dla zaistnienia symulacji w znaczeniu ścisłym jest zatem wymagane, aby czynność została wykonana w całości, ze wszystkimi swoimi istotnymi elementami, ale bez należytej dla danej czynności intencji. To właśnie brak wymaganej intencji jest istotnym elementem symulacji, powodującym nieważność wykonywanej czynności ${ }^{52}$. W przypadku sakramentów ten zamiar, intencja, są wymogiem prawa boskiego. Sprawujący sakrament musi mieć intencję czynienia tego, co czyni Kościół. Brak takiej intencji powoduje nieważność sakramentów, które nie mogą zostać uzdrowione nawet z upływem czasu $^{53}$. W przypadku przestępstwa symulacji czynności liturgicznej Ofiary Eucharystycznej będziemy mieli do czynienia z kapłanem, wy-

${ }^{50}$ Będzie tutaj mowa o tych, którzy są szafarzami danego sakramentu, a zatem o diakonach (np. w przypadku sakramentu chrztu), prezbiterach (np. w przypadku sakramentu namaszczenia chorych, czy Eucharystii), biskupach (np. w przypadku sakramentu kapłaństwa, czy Eucharystii), a także świeckich (np. w przypadku sakramentu małżeństwa), por. A. Calabrese, Diritto penale..., s. 305.

${ }^{51}$ Por. V. De Paolis - D. Cito, Le sanzioni nella Chiesa..., s. 333. Zob. także D. Cito, Delicta graviora..., s. 42.

${ }^{52}$ L. Chiappetta, Prontuario di Diritto Canonico e Concordatario, 1994, s. 1145.

${ }^{53} \mathrm{~W}$ myśl zasady prawnej podanej przez prawnika rzymskiego Paulusa: Quod initio vitiosum est, non potest tractu temporis convalescere (D. 50, 17, 29). Por. V. De Paolis - D. Ciтo, Le sanzioni nella Chiesa..., s. 332. 
konującym wprawdzie czynność liturgiczną Ofiary Eucharystycznej, ale nie mającym odpowiedniej intencji - zamiaru ważnego sprawowania sakramentu Eucharystii ${ }^{54}$. Wówczas kapłan z pełną świadomością i wolnością wprowadza w błąd wiernych, że rzeczywiście sprawuje autentyczną Ofiarę Eucharystyczną ${ }^{55}$. Symulowanie sakramentu Eucharystii może być dokonane także poprzez, świadome i dobrowolne, użycie przez kapłana materii niewłaściwej dla tego sakramentu, np. płynów innych aniżeli wino ${ }^{56}$. Oprócz symulacji w znaczeniu ścisłym, w doktrynie mówi się także o symulacji w ujęciu tradycyjnym. Przez symulację w ujęciu tradycyjnym rozumie się także i te sytuacje, kiedy podmiot popełniający przestępstwo nie posiada wymaganej zdolności, a jednak w sposób zamierzony dokonuje wszystkich czynności, jakie składają się na dany znak sakramentalny, wzbudzając $w$ adresatach przekonanie o ważności sakramentu ${ }^{57}$. Należy jednak zaznaczyć, że symulacja czynności liturgicznej Ofiary Eucharystycznej nie jest tym samym co usiłowanie tejże czynności. Usiłuje czynności liturgicznej Ofiary Eucharystycznej, ten kto nie mając wymaganej zdolności uzurpuje sobie taką zdolność z pobudek, o których była mowa wcześniej. Natomiast symuluje czynność liturgiczną Ofiary Eucharystycznej, w omawianym ujęciu tradycyjnym, osoba nie posiadająca wprawdzie wymaganej zdolności, ale też nie uzurpująca sobie do tego pretensji.

${ }^{54}$ A. Calabrese zwraca tutaj uwagę na fakt, iż sprawowanie czynności liturgicznych Ofiary Eucharystycznej przez kapłana podlegającego suspensie lub ekskomunikowanego albo też takiego, który utracił wiarę, nie jest symulacją, jest ważne, chociaż niegodziwe, por. A. Calabrese, Diritto penale..., s. 301.

${ }^{55}$ Por. D. Ciтo, Delicta graviora..., s. 42.

${ }^{56}$ Por. D.G. Astigueta, Ultime modifiche al motu proprio delicta graviora, w: Il quindicesimo anniversario dell'istituto di diritto canonico "Ad instar facultatis" dell’Università Cattolica Pázmány Péter, red. Sz. Anzelm Szuromi, Budapeszt 2011, s. 74. B.F. Pighin, komentując kan. 1379, uważa ponadto, że przestępstwo symulowania czynności liturgicznej Ofiary Eucharystycznej miałoby miejsce także w przypadku świadomego udzielania komunii św. komunikantami nie konsekrowanymi, B.F. PIGHIN, Diritto penale ..., s. 396-397. Należy jednak podkreślić, że spośród różnych możliwych form symulacji sakramentu Eucharystii zawartych w dyspozycji kan. 1379, Kongregacji Nauki Wiary zostało zarezerwowane tylko jedno działanie polegające na wykonaniu czynności liturgicznej Ofiary Eucharystycznej.

${ }^{57}$ Por. V. De Paolis - D. Cito, Le sanzioni nella Chiesa..., s. 333. 
Wprowadza innych w błąd z pobudek materialnych lub innych. Będzie tutaj mowa o osobach, które przykładowo w celach zbiórki pieniędzy, czy też z innych pobudek udają kapłanów i dla uwiarygodnienia swojej pozycji sprawują liturgię Eucharystyczną ${ }^{58}$. Symulacja czynności liturgicznej Ofiary Eucharystycznej, jak się wydaje może być zatem rozumiana zarówno w znaczeniu ścisłym jak i w ujęciu tradycyjnym ${ }^{59}$. W związku z powyższym, gdyby czynności liturgicznej Ofiary Eucharystycznej dokonała osoba nie będąca kapłanem to, w zależności od motywów jej działania, mielibyśmy do czynienia albo z przestępstwem usiłowania tejże czynności, albo właśnie z jej symulacją w szerokim znaczeniu.

1.4. Koncelebrowanie Ofiary Eucharystycznej z szafarzami wspólnot kościelnych, które nie posiadają sukcesji apostolskiej oraz nie uznają sakramentalności święceń kapłańskich

Czwarte z przestępstw skierowanych przeciwko Najświętszej Eucharystii, należące do kategorii delicta reservata, to koncelebracja Eucharystii z szafarzami wspólnot kościelnych, które nie posiadają sukcesji apostolskiej oraz nie uznają sakramentalności święceń kapłańskich $^{60}$. Przestępstwo to brane jest pod uwagę, w ramach tzw. vetita communicatio in sacris, zarówno w Kodeksie Prawa Kanonicznego z 1983 roku $^{61}$, jak i w Kodeksie Kanonów Kościołów Wschodnich

\footnotetext{
${ }^{58}$ Por. tamże, s. 330.

${ }^{59}$ Por. A.G. Urru, Punire per salvare..., s. 225; D.G. Astigueta, Ultime modifiche al motu proprio..., s. 74.

${ }^{60}$ Art. 3: , $\S 1$, n. 4 vetita in can. 908 Codicis Iuris Canonici et in can. 702 Codicis Canonum Ecclesiarum Orientalium eucharistici Sacrificii concelebratio, de qua in can. 1365 Codicis Iuris Canonici et in can. 1440 Codicis Canonum Ecclesiarum Orientalium, una cum ministris communitatum ecclesialium, qui successionem apostolicam non habent nec agnoscunt ordinationis sacerdotalis sacramentalem dignitatem", CoNgregatio pro Doctrina FideI, Normae de delictis Congregationi pro Doctrina Fidei reservatis..., s. 422.

${ }^{61}$ KPK/1983, kann. 1365, 908. Zob. także KPK/1983, kann. 844, 205.
} 
z 1990 roku $^{62}$. Normy De gravioribus delictis z 2001 roku zawierały tutaj podobną dyspozycję ${ }^{63}$.

Omawiane przestępstwo wiąże się z tzw. communcatio in sacris, czyli z uczestnictwem w kulcie liturgicznym lub w sakramentach innego Kościoła bądź wspólnoty chrześcijańskiej ${ }^{64}$. W Kodeksie Prawa Kanonicznego z 1917 roku czynna communicatio in sacris była przedmiotem całkowitego zakazu ${ }^{65}$. Aktualny Kodeks Prawa Kanonicznego jest w tym względzie mniej rygorystyczny, albowiem w pewnych okolicznościach dopuszcza czynną communicatio in sacris ${ }^{66}$. Takie nastawienie obecnego Kodeksu jest w zgodzie z ekumeniczną linią Soboru Watykańskiego II, który w niektórych przypadkach zaleca communicatio in sacris ${ }^{67}$, oczywiście winna ona przebiegać z zachowaniem przepisów kościelnych ${ }^{68}$. Niemniej jednak należy zauważyć, iż pomimo tej otwartości, communicatio in sacris jest z zasady zakazana. Aktualny Kodeks Prawa Kanonicznego przypomina o tym z jednej strony, w fundamentalnej zasadzie wyrażonej w kan. $844 \S 1$, według której katoliccy szafarze udzielają godziwie sakramentów tylko wiernym katolikom, którzy też godziwie przyjmują je tylko od szafarzy katolickich, z drugiej natomiast strony w przepisie zawartym w kan. 1365 przewidującym obowiązek ukarania sprawiedliwą karą winnego zakazanego uczestnictwa w rzeczach świętych.

${ }^{62}$ KKKW/1990, kann. 1440, 702.

${ }^{63}$ Por. Congregatio pro Doctrina Fidei, Epistula..., s. 786. Zob. G. NúÑEz, La competencia penal..., s. 374-375; D. Borek, Ordynariusz a $<$ Delicta Graviora $>$..., s. 110113.

${ }^{64}$ Communicatio in sacris należy odróżnić od communicatio in spiritualibus, które oznacza całokształt wzajemnych kontaktów duchowych między katolikami i innymi chrześcijanami, a zatem uczestnictwo w modlitwach, rzeczach i miejscach świętych, oraz od communicatio in profanis, które natomiast oznacza współudział w rzeczach doczesnych, por. T. PAwluk, Prawo kanoniczne wedtug Kodeksu Jana Pawła II, t. IV, Olsztyn 1990, s. 126.

${ }^{65}$ Por. KPK/1917, kan. 1258. Zob. także. M. BAJCAR, Delitti contro la religione e l'unità della Chiesa con particolare riferimento alla „Communicatio in sacris”, confronto tra il CIC 1983 e il CCEO 1990, Roma 1998, s. 71-74.

${ }^{66}$ Por. KPK/1983, kan. 844.

${ }^{67}$ Sobór Watykański II, Dekret o ekumeniźmie, Unitatis Redintegratio, n. 8.

${ }^{68}$ Por. V. De Paolis - D. Cito, Le sanzioni nella Chiesa..., s. 301-302. 
Vetita communicatio in sacris, a więc zakazane uczestnictwo w rzeczach świętych może przybrać różne formy i może się wiązać z: udzielaniem sakramentów osobom, które nie przyjęły jeszcze sakramentu chrztu (KPK/1983, kan. 842 §); wiernym Kościoła katolickiego, który przyjmowałby sakramenty pokuty, Eucharystii i namaszczenia chorych od szafarzy niekatolickich Kościoła, w którym wprawdzie są ważne wspomniane sakramenty, ale gdyby nie były spełnione warunki stawiane przez KPK/1983 w kan. 844 §2; szafarzem katolickim, który udzielałby wyżej wspomnianych sakramentów wiernym Kościołów wschodnich niekatolickich, gdyby oni sami o to nie prosili i nie byli odpowiednio dysponowani (KPK/1983, kan. 844 § 3); szafarzem katolickim, który udzielałby wyżej wspomnianych sakramentów pozostałym chrześcijanom nie mającym pełnej wspólnoty z kościołem katolickim, gdyby nie były spełnione wymagane warunki (KPK/1983, kan. 844 § 4); dopuszczeniem niekatolika do pełnienia zadania chrzestnego (KPK/1983, kan. 874); zakazem koncelebrowania Eucharystii z kapłanami lub szafarzami niekatolickimi (KPK/1983, kan. 908); zakazem sprawowania Eucharystii w świątyni jakiegoś Kościoła lub wspólnoty kościelnej niekatolickiej, bez wyraźnej zgody ordynariusza miejsca (KPK/1983, kan. 933); pogrzebem kościelnym niekatolików bez spełnienia warunków o których mowa w KPK/1983, kan. 1183 § 3. Aktualny Kodeks Prawa Kanonicznego przewiduje zatem cały szereg sytuacji, kiedy communicatio in sacris jest zakazana, ewentualne naruszenia tych zakazach będą skutkować popełnieniem przestępstwa, o którym w kan. 1365.

Należy jednak zaznaczyć, że spośród wyżej wymienionych możliwych naruszeń w zakresie vetita communicatio in sacris, Kongregacji Nauki Wiary zostały zarezerwowane wyłącznie te, które są związane ze sprawowaniem sakramentu Eucharystii w myśl KPK/1983 kan. 908 oraz w KKKW/1990 kan. 702, ale i tutaj z pewnym ograniczeniem. Otóż w kan. 908 ustawodawca zabrania katolickim kapłanom koncelebrowania Eucharystii z kapłanami lub szafarzami kościołów lub wspólnot kościelnych nie mających pełnej wspólnoty z Kościołem katolickim. Podobnie stawia sprawę ustawodawca w Kodeksie dla Ko- 
ściołów Wschodnich w kan. 702. W myśl cytowanych kanonów przestępstwo polega tutaj na koncelebrowaniu Eucharystii przez kapłana katolickiego z kapłanem czy szafarzem jakiegokolwiek Kościoła czy wspólnoty kościelnej nie posiadających pełnej wspólnoty z Kościołem Katolickim. Ustawodawca wymaga zatem od współkoncelebransów pełnej wspólnoty kościelnej, w myśl kan. 205 KPK/1983, w przeciwnym razie kapłan katolicki popełnia przestępstwo i powinien być ukarany w myśl kan. 1365 KPK/1983. Gdyby zatem zaistniała taka sytuacja, Ordynariusz powinien podjąć przewidziane kroki. Kongregacji Nauki Wiary zostały zarezerwowane jedynie takie sytuacje, kiedy kapłan katolicki koncelebruje Eucharystię z szafarzami jedynie tych wspólnot kościelnych, które nie posiadają sukcesji apostolskiej oraz nie uznają sakramentalności święceń kapłańskich. W tej perspektywie będzie przestępstwem, w myśl kann. 908 i 1365 KPK/1983, koncelebra Eucharystii szafarza katolickiego z szafarzem prawosławnym, takie przestępstwo jednak nie jest zarezerwowane Kongregacji ${ }^{69}$. W takim przypadku Ordynariusz winien sam podjąć kroki zmierzające do pociagnięcia do odpowiedzialności karnej sprawcę takiego przestępstwa.

\subsection{Konsekracja, in sacrilegum finem, jednej postaci lub obydwu w czasie Eucharystycznej celebracji lub też poza nią}

Piąte, i ostatnie przestępstwo z grupy przestępstw dotyczących Najświętszej Eucharystii i zarezerwowanych Kongregacji Nauki Wiary, to konsekracja in sacrilegum finem jednej postaci lub obydwu w czasie Eucharystycznej celebracji lub też poza nią ${ }^{70}$. Źródłem bezpośrednim takiego przepisu jest kan. 927 Kodeksu Prawa Kanonicznego z 1983 roku $^{71}$, który $\mathrm{z}$ kolei prawie dosłownie przejął to, co $\mathrm{w}$ tej materii

${ }^{69}$ Por. D. Cito, Delicta graviora..., s. 43. Zob. także V. De Paolis, Norme de gravioribus delictis..., s. 302-303.

${ }^{70}$ Art. 3: "§ 2 Congregationi pro Doctrina Fidei reservatur quoque delictum quod consistit in consecratione in sacrilegum finem unius materiae vel utriusque in eucharistica celebratione, aut extra eam", Congregatio PRo Doctrina Fidei, Normae de delictis Congregationi pro Doctrina Fidei reservatis..., s. 422.

${ }^{71}$ Kanon 927 KPK/1983 jest wyrazem doktryny ogólnie przyjętej w tej materii, por. V. De PAolis, Norme de gravioribus delictis..., s. 303. Wprawdzie 
przewidywał kan. 817 Kodeksu Prawa Kanonicznego z 1917 roku $^{72}$. Nie znajdujemy natomiast podobnego przepisu w Kodeksie Kanonów Kościołów Wschodnich z 1990 roku. Należy ponadto zaznaczyć, że ani KPK/1983, ani KKKW/1990 nie posiadał omawianego naruszenia w katalogu poszczególnych przestępstw. Normy z 2001 roku przewidywały omawianą formę przestępstwa, ale ujmowały ją nieco ina$\mathrm{czej}^{73}$. We wspomnianych Normach była mowa o konsekracji w celach świętokradczych, jednej postaci bez drugiej w czasie celebracji Eucharystycznej, oraz o konsekracji obydwu postaci, ale poza celebracją Eucharystyczną.

Omawiane przestępstwo, jak to wynika z Norm De delictis reservatis z 2010 roku, może przybrać dwie formy: po pierwsze - może polegać na dokonaniu konsekracji in sacrilegum finem jednej postaci lub obydwu w czasie Eucharystycznej celebracji; po drugie - może polegać na dokonaniu konsekracji jednej postaci lub obydwu, zawsze in sacrilegum finem, ale poza sprawowaniem Eucharystii.

obowiązujący Kodeks Prawa Kanonicznego nie przewiduje wprost kary za zachowanie niezgodne z tym, co się przewiduje w kan. 927, niemniej jednak w celu wymierzenia kary możemy się tutaj odwołać do kan. 1384 wspomnianego Kodeksu. Otóż w kanonie tym czytamy: „Kto oprócz wypadków, o których w kan. 1378-1383, niezgodnie z prawem sprawuje zadanie kapłańskie lub inną świętą posługę, może być ukarany sprawiedliwą karą". Poprzez ten ogólny przepis Kościół zmierza do ukarania każdego niezgodnego z prawem wykonywania zadań kapłańskich lub posług świętych, które nie zostały wzięte pod uwagę w kann. 1378-1383. Bez wątpienia konsekracja in sacrilegum finem jednej postaci lub obydwu w czasie Eucharystycznej celebracji lub też poza nią może być zakwalifikowana do przestępstw, które podlegają karze zgodnie z kan. 1384. Kara, jaką się tutaj przewiduje, to kara ferendae sententiae, fakultatywna i nie określona, a zatem pozostawiona roztropnemu uznaniu Ordynariusza albo też sędziego, por. A.G. Urru, Punire per salvare..., s. 232.

${ }^{72}$ KPK/1917, kan. 817.

${ }^{73}$ Por. Congregatio pro Doctrina Fidei, Epistula..., s. 786. Zob. G. NúÑEz, La competencia penal..., s. 375-376; D. BoreK, Ordynariusz a $<$ Delicta Graviora > ..., s. 113116. 
W związku z pierwszą formą przestępstwa należy stwierdzić, że podczas sprawowania Mszy świętej powinno się dokonać konsekracji obydwu postaci, to jest chleba i wina. Wynika to z samego prawa Boskiego, ponieważ Chrystus podczas ostatniej wieczerzy ofiarował Bogu Ojcu Ciało i Krew swoją pod postaciami chleba i wina, tak też polecił czynić swoim Apostołom i ich następcom mówiąc: „To czyńcie na moją pamiątkę" (Łk 22, 9). Chrystus polecił zatem składać Jego Ofiarę pod dwiema postaciami, dlatego też kapłani nie mogą dokonywać konsekracji jednej tylko postaci, czy to podczas Mszy św., czy też poza nią ${ }^{74}$. Nie będzie jednak przestępstwem dokonanie konsekracji tylko jednej postaci podczas Mszy św. w sytuacji, gdy kapłan zauważy dopiero po konsekracji lub nawet w czasie Komunii św., że w kielichu ma nie wino, ale samą wodę. W takiej sytuacji, zgodnie z zaleceniem, jakie znajdujemy we wprowadzeniu do Mszału Rzymskiego, kapłan powinien usunąć wodę do jakiegoś naczynia, a następnie wlać do kielicha wino z wodą i dokonać konsekracji, wypowiadając słowa dotyczące konsekracji kielicha, nie ma natomiast obowiązku powtórnego konsekrowanie chleba ${ }^{75}$. W myśl kan. 927 niedopuszczalna jest zatem, oczywiście oprócz sytuacji powyżej opisanej, konsekracja tylko jednej postaci czy to wina, czy chleba. Zakaz ten nie ulega zawieszeniu nawet w sytuacji ostatecznej konieczności. Ponadto, zgodnie z nowymi dyspozycjami, przestępstwem będzie także konsekracja obydwu postaci podczas Mszy św. ale w celu świętokradczym.

Podobnie jak wyżej, nie godzi się, nawet w sytuacji ostatecznej konieczności, dokonywać konsekracji jednej albo obydwu postaci poza sprawowaniem Eucharystii. Powyższy zakaz wynika z faktu, że Ostatnia Wieczerza była doroczną wieczerzą paschalną obchodzoną według pewnego rytuału. Chrystus podczas Ostatniej Wieczerzy przemienił chleb i wino w swoje Ciało i Krew w pewnym kontekście, i dlatego dzisiaj Kościół pragnie, aby konsekracja dokonywała się jedynie

${ }^{74}$ M. PastuszKo, Obrzędy i ceremonie sprawowania Eucharystii (kanony 923-930), Prawo Kanoniczne 36 (1993) nr 1-2, s. 101.

${ }^{75}$ Kongregacja Kultu Bożego i Dyscypliny Sakramentów, Nowe Ogólne Wprowadzenie do Mszatu..., n. 324, s. 91. 
w czasie obrzędów Mszy świętej ${ }^{76}$. Msza św. posiada i dzisiaj ściśle określoną strukturę, na którą oczywiście składają się dwie zasadnicze części, mianowicie liturgia słowa i liturgia eucharystyczna, które są tak ściśle ze sobą złączone, że stanowią jeden akt kultu. Oprócz tego niektóre obrzędy rozpoczynają i kończą celebrację ${ }^{77}$. Kanon 927 aktualnego Kodeksu traktuje liturgię Eucharystyczną w sposób całościowy, a to oznacza, że nie można swobodnie w niej przebierać pomijając niektóre jej części. Niedopuszczalna jest zatem konsekracja postaci Eucharystycznych, jednej lub obydwu, poza liturgią Mszy św.

Mając na uwadze powyższe spostrzeżenia należy stwierdzić, że w każdym z obydwu przewidzianych w nowych normach przypadków, mamy do czynienia z bardzo poważnym zakazem, który nie dopuszcza wyjątków, nawet w sytuacjach ostatecznej konieczności. Jakiekolwiek wykroczenie będzie tutaj zawsze niegodziwe (nefas est). Należy jednak zaznaczyć, że przestępstwem zarezerwowanym Kongregacji będą tylko te wykroczenia, które zostaną popełnione in sacrilegum finem, czyli z wyraźnym zamiarem świętokradczym ${ }^{78}$. Cel świętokradczy może się wyrażać w tych samych motywach i działaniach, o których była mowa w przypadku przestępstwa profanacji postaci konsekrowanych. Konsekracja in sacrilegum finem jednej lub obydwu postaci w czasie Mszy św., czy też poza nią może być dokonywana po to, aby przeznaczyć postacie konsekrowane do aktów bezwstydnych i bezbożnych, do celebracji czarnych mszy, rytów satanistycznych lub masońskich, magii, wróżbiarstwa lub innego rodzaju zabobonów ${ }^{79}$. Na uwagę zasługuje ponadto fakt, że autorem tego przestępstwa może być tylko kapłan ważnie wyświęcony ${ }^{80}$. Należy przyjąć, że będzie on winny omawianego przestępstwa, zarówno wtedy, kiedy sam dokona

${ }^{76}$ M. Pastuszko, Obrzędy i ceremonie sprawowania Eucharystii..., nr 1-2, s. 102.

${ }^{77}$ Por. Kongregacja Kultu Bożego i Dyscypliny Sakramentów, Nowe Ogólne Wprowadzenie do Mszatu..., n. 28, s. 20.

${ }^{78}$ B.E. FERME, Graviora delicta: the apostolic letter M.P. sacramentorum sanctitatis tutela, w: Il processo penale canonico, red. Z. Suchecki, Roma 2003, s. 377.

${ }^{79}$ A. Calabrese, Diritto penale..., s. 272-273.

${ }^{80}$ Por. przestępstwo usiłowania czynności liturgicznej ofiary Eucharystycznej. 
konsekracji i profanacji postaci konsekrowanych ${ }^{81}$, jak i wtedy, kiedy będzie on jedynie świadomym autorem konsekracji postaci, które później będą sprofanowane przez kogoś innego.

Zgodnie z aktualnym sformułowaniem nie ma znaczenia czy będzie konsekrowana tylko jedna czy obydwie postaci, w czasie celebracji Eucharystycznej czy też poza nią, istotny jest natomiast charakter świętokradczy takiej konsekracji ${ }^{82}$. Aktualne sformułowanie wydaje się być bardziej precyzyjne, co pozwala uniknąć ewentualnych trudności interpretacyjnych, jakie można było napotkać w odniesieniu do poprzedniej wersji ${ }^{83}$.

\section{Przestępstwa przeciwko świętości sakramentu pokuty}

Po Najświętszej Eucharystii, przedmiotem szczególnej troski ze strony Kościoła jest sakrament pokuty. Sakrament pokuty jest i powinien pozostać zawsze szczególnym miejscem pojednania z Bogiem i z Kościołem, a nie miejscem zgorszenia i grzechu, dlatego też Kościół zabiega o to, aby sakrament ten był sprawowany we właściwy i godziwy sposób. W Normach De delictis reservatis z 2010 roku Kongregacji Nauki Wiary zostało zarezerwowanych następujących sześć przestępstw przeciwko świętości sakramentu pokuty: rozgrzeszenie wspólnika w grzechu przeciwko szóstemu przykazaniu Dekalogu; usiłowanie rozgrzeszenia sakramentalnego lub zakazane słuchanie spowiedzi; symulowanie rozgrzeszenia sakramentalnego; sollicitatio ad turpia, jeżeli ma na celu grzech z samym spowiednikiem; bezpośrednia i pośrednia zdrada tajemnicy sakramentalnej; nagrywanie przy pomocy jakiegokolwiek instrumentu technicznego, lub rozpowszechnianie za pomocą środków społecznego przekazu dokonane ze złośliwością tego, co jest mówione przez spowiednika lub penitenta

${ }^{81}$ Jak się wydaje będzie tutaj miał miejsce realny zbieg przestępstw, o którym w kan. 1346. Zob. J. Syry jCZyK, Sankcje w Kościele..., s. 273-276.

${ }^{82}$ D.G. Astigueta, Ultime modifiche al motu proprio..., s. 75. Por. także D.G. AstiGUETA, La consagraciòn con fin ascrílego: la intención del ministro, Periodica 98 (2009), s. 33-80.

${ }^{83}$ Por. D. Ciтo, Delicta graviora..., s. 39; 43. 
podczas spowiedzi sakramentalnej, prawdziwej lub fałszywej ${ }^{84}$. Motu Proprio Sacramentorum sanctitatis tutela z 2001 roku do kategorii najcięższych przestępstw zarezerwowanych Kongregacji Nauki Wiary zaliczało jedynie trzy następujące przestępstwa przeciwko świętości sakramentu pokuty: rozgrzeszenie wspólnika w grzechu przeciwko szóstemu przykazaniu Dekalogu; sollicitatio ad turpia, jeżeli ma na celu grzech z samym spowiednikiem; bezpośrednie naruszenie tajemnicy sakramentalnej ${ }^{85}$. W porównaniu zatem z Normami z 2001 roku, obecnie w kategorii delicta reservata została zawarta większa liczba przestępstw przeciwko sakramentowi pokuty. Taka zmiana z jednej strony wskazuje na wielką troskę, z jaką Kościół dba o zagwarantowanie godziwego sprawowania sakramentu pokuty, ale z drugiej strony, co może być bardzo niepokojące, wskazuje na zdarzające się stosunkowo często nadużycia w związku ze sprawowaniem tego sakramentu ${ }^{86}$.

W materii karania za przestępstwa przeciwko świętości sakramentu pokuty zachowują moc dyspozycje zawarte w kanonach zajmujących się poszczególnymi przestępstwami. W odniesieniu natomiast do przestępstwa polegającego na nagrywaniu i/lub rozpowszechnianiu tego, co jest mówione podczas spowiedzi przewidziany jest obowiązkowy wymiar kar ferendae sententiae w postaci kary nieokreślonej, która będzie uzależniona od ciężkości przestępstwa, oraz w przypadku duchownego kary określonej dymisji lub depozycji ${ }^{87}$.

${ }^{84}$ Congregatio pro Doctrina Fidei, Normae de delictis Congregationi pro Doctrina Fidei reservatis..., s. 422-423.

${ }^{85}$ Por. Congregatio pro Doctrina Fidei, Epistula..., s. 786-787. Zob. V. De Paolis, Norme de gravioribus..., s. 304-308.

${ }^{86}$ Por. D. Ciтo, Delicta graviora..., s. 43-44. Por. także D. Ciто, La protezione giuridica del sacramento della Penitenza, w: Quaderni della Mandolla 18, Milano 2010, s. 269-285.

${ }^{87}$ Art. 4: "§ 2 Qui hoc delictum patraverit, pro gravitate criminis puniatur, non exclusa, si clericus est, dimissione vel depositione", Congregatio PRo Doctrina FIDEI, Normae de delictis Congregationi pro Doctrina Fidei reservatis..., s. 423. 
2.1. Rozgrzeszenie wspólnika w grzechu przeciwko szóstemu przykazaniu Dekalogu

Pierwsze spośród delicta graviora contra sanctitatem sacramenti Paenitentiae to przestępstwo polegające na rozgrzeszeniu wspólnika w grzechu przeciwko szóstemu przykazaniu Dekalogu ${ }^{88}$. Przestępstwo to jest przewidziane zarówno w Kodeksie Prawa Kanonicznego z 1983 roku $^{89}$, jak i w Kodeksie Kanonów Kościołów Wschodnich z 1990 roku $^{90}$. Normy De gravioribus delictis z 2001 roku zawierały w tej materii identyczną dyspozycję ${ }^{91}$. Do zaistnienia omawianego przestępstwa muszą mieć miejsce następując trzy elementy: po pierwsze - grzech ciężki przeciwko szóstemu przykazaniu Dekalogu; po drugie - relacja współdziałania w powyższym grzechu pomiędzy kapłanem rozgrzeszającym a rozgrzeszanym; po trzecie - udzielenie rozgrzeszenia od powyższego grzechu, tzn. wypowiedzenie formuły absolucji.

Kanon 977 zakazuje rozgrzeszania wspólnika, pod sankcją nieważności, jedynie w przypadku grzechu przeciwko szóstemu przykazaniu Dekalogu. W związku z czym inne grzechy, chociaż by były jak najbardziej poważne, ale nie dotyczące szóstego przykazania Dekalogu, nie są tutaj brane pod uwagę. Należy zaznaczyć, że nie wchodzi tutaj $\mathrm{w}$ grę jakikolwiek grzech $\mathrm{w}$ interesującej nas materii, ale jedynie grzech ciężki. Należałoby więc wykluczyć tutaj te wszystkie przypadki, kiedy przynajmniej jedna ze stron, z różnych powodów, np. stanu psychicznego, nie popełniła grzechu ciężkiego ${ }^{92}$. Zgodnie z kan. 1321

${ }^{88}$ Art. 4: " $\$ 1$, n. 1 absolutio complicis in peccato contra sextum Decalogi praeceptum, de qua in can. $1378 \S 1$ Codicis Iuris Canonici et in can. 1457 Codicis Canonum Ecclesiarum Orientalium", Congregatio pro Doctrina Fidei, Normae de delictis Congregationi pro Doctrina Fidei reservatis..., s. 422.

${ }^{89} \mathrm{KPK} / 1983$, kann. $1378 \S 1,977$.

${ }^{90}$ KKKW/1990, kann. 1457, 728 § 1 n. 2.

${ }^{91}$ Por. Congregatio pro Doctrina Fidei, Epistula..., s. 786. Zob. G. NúÑEz, La competencia penal..., s. 377-378; D. BoreK, Ordynariusz a $<$ Delicta Graviora > .., s. 116119.

${ }^{92}$ Por. G.P. Montini, La tutela del sacramento della penitenza. I delitti nella celebrazione del sacramento (cann. 1378; 1387; 1388), w: Le sanzioni nella Chiesa, red. Gruppo Italiano Docenti di Diritto Canonico, Milano 1997, s. 219. 
$\S 1 \mathrm{KPK} / 1983$ nie można nikogo karać, jeżeli nie miało miejsca zewnętrzne naruszenie przepisu. Dlatego też w omawianym przypadku grzechy przeciwko szóstemu przykazaniu Dekalogu muszą być zarówno wewnętrzne, jak i zewnętrzne, chociaż mogą przybrać różne formy ${ }^{93}$.

Współudział oznacza, że w tym samym grzechu biorą udział, świadomie i dobrowolnie, przynajmniej dwie osoby, ale oczywiście może być ich więcej. Wspólnikiem może być jakakolwiek osoba, która wyraża zgodę na popełnienie grzechu. Jeżeli nie ma takiej zgody, to też nie można mówić o współudziale ${ }^{94}$. Grzech ciężki musi być zatem popełniony przez wszystkich, a nie jedynie przez spowiednika. Wspólnikiem może tutaj być jakakolwiek osoba zdolna do popełnienia grzechu ciężkiego, i która rzeczywiście popełniła ze spowiednikiem taki grzech $^{95}$. Nie ma właściwie znaczenia czas, to znaczy moment, kiedy dany grzech został popełniony. $\mathrm{W}$ tej perspektywie nie będzie miało znaczenia, czy w momencie popełniania grzechu przeciwko szóstemu przykazaniu kapłan był już kapłanem, czy też współudział miał miejsce nawet na długo przed przyjęciem przez kapłana święceń ${ }^{96}$.

Omawiane przestępstwo zostanie jednakże popełnione dopiero z chwila, gdy kapłan wypowie słowa sakramentalnej absolucji, posiadając przy tym intencję jej udzielenia ${ }^{97}$. Należy zaznaczyć, że, w myśl kan. $1378 \S 1$, przestępstwem będzie jedynie nieważne udzielenie absolucji. Jest to o tyle istotne, że mogą zaistnieć takie sytuacje, kiedy spowiednik będzie jednak ważnie rozgrzeszał wspólnika z grzechu przeciwko szóstemu przykazaniu Dekalogu. Otóż jest to przede wszystkim sytuacja niebezpieczeństwa śmierci; w takiej sytuacji spowiednik zachowuje upoważnienie do spowiadania. Ponadto zakaz, o którym w kan. 977

${ }^{93}$ Por. A. Calabrese, Diritto penale..., s. 299.

${ }^{94} \mathrm{~W}$ przypadku braku takiej zgody możnaby ewentualnie mówić o innych przestępstwach, o których w kan. 1395, por. P. BARBERo, Tutela della comunione ecclesiale..., s. 207.

${ }^{95}$ Por. J. SyRYJCZYK, Kanoniczne prawo karne..., s. 97-98.

${ }^{96}$ Por. P. MontinI, La tutela penale del sacramento della penitenza..., s. 218219.

${ }^{97}$ Por. J. SyryjczyK, Kanoniczne prawo karne..., s. 98. 
obejmuje jedynie te grzechy, które jeszcze nie zostały odpuszczone, zatem nie będzie przestępstwa w sytuacji, gdy wspólnik już raz wcześniej otrzymał rozgrzeszenie danego grzechu ${ }^{98}$. Należ tutaj jeszcze zaznaczyć, że zgodnie z kan. 1321 § 2 KPK/1983, dla zaistnienia przestępstwa spowiednik musi działać rozmyślnie, naruszając zakaz zawarty w kann. 1378 § 1 i 977, nie zaciąga bowiem kary, jeżeli przekroczył ustawę wskutek zaniedbania należytej staranności. Spowiednik musi zatem wiedzieć, że usiłuje udzielić rozgrzeszenia swojemu wspólnikowi w grzechu przeciwko szóstemu przykazaniu Dekalogu i że takie rozgrzeszenie jest mu zabronione i pomimo to udziela tego rozgrzeszenia ${ }^{99}$.

Ze względu na tajny charakter tego przestępstwa, raczej do rzadkości będzie należało rozpatrywanie go przez Kongregację Nauki Wiary. W celu uzyskania zwolnienia z kary ekskomuniki latae sententiae będzie raczej konieczne skierowanie się do Penitencjarni Apostolskiej ${ }^{100}$.

\subsection{Usiłowanie rozgrzeszenia sakramentalnego lub zakazane słuchanie spowiedzi}

W ramach ochrony świętości sakramentu pokuty, Kongregacji Nauki Wiary zostało zarezerwowane także przestępstwo polegające na uzurpowaniu władzy spowiednika. Przestępstwo to jest przewidziane w Kodeksie Prawa Kanonicznego z 1983 roku w kan. 1378 § 2, n. $2^{101}$, brakuje natomiast analogicznej dyspozycji w Kodeksie Kanonów Kościołów Wschodnich z 1990 roku. Także Normy De gravioribus delictis z roku 2001 nie zawierały analogicznej dyspozycji. W Normach De delictis reservatis z 2010 roku jest mowa o dwóch formach uzurpacji władzy spowiednika: po pierwsze o usiłowaniu rozgrzeszenia sakramentalnego; po drugie o zakazanym słuchaniu spowiedzi ${ }^{102}$.

\footnotetext{
${ }^{98}$ Por. Communicationes 15 (1983), s. 210.

${ }^{99}$ Por. G.P. Montini, La tutela del sacramento della penitenza..., s. 220.

${ }^{100}$ Por. D. Cito, Delicta graviora..., s. 44. Zob. P. BArbero, Tutela della comunione ecclesiale..., s. 207-208.

${ }^{101}$ KPK/1983, kan. 1378 § 2, n. 2.

${ }^{102}$ Art. 4: "§ 1, n. 2 attentatio sacramentalis absolutionis vel vetita confessionis auditio de quibus in can. $1378 \S 2$ n. 2 Codicis Iuris Canonici”, Congregatio Pro DoctrINA FIDEI, Normae de delictis Congregationi pro Doctrina Fidei reservatis..., s. 422.
} 
U podstaw omawianego przestępstwa, które w doktrynie określane jest jako uzurpowanie władzy spowiednika znajduje się brak wymaganych święceń w stopniu prezbiteratu lub, w przypadku prezbiterów, brak wymaganego prawem kościelnym upoważnienia ${ }^{103}$. Do ważnego sprawowania sakramentu pokuty muszą być spełnione warunki, o których w kann. 965 oraz 966 Kodeksu Prawa Kanonicznego z 1983 roku. Zgodnie z pierwszym z cytowanych kanonów szafarzem sakramentu pokuty może być jedynie kapłan ${ }^{104}$. Tenże kapłan, do ważnego sprawowania sakramentu pokuty, musi posiadać, oprócz władzy święceń, także upoważnienie do wykonywania tejże władzy w odniesieniu do wiernych, którym udziela rozgrzeszenia ${ }^{105}$. Takie upoważnienie może posiadać, albo na mocy prawa ipso iure ${ }^{106}$, albo na mocy urzędu vi officii ${ }^{107}$, albo w wyniku specjalnego udzielenia ${ }^{108}$. Upoważnienie do spowiadania można utracić na różne sposoby, w wyniku upływu czasu na jaki zostało dane ${ }^{109}$, poprzez odwołanie dokonane przez kompetentną władzę ${ }^{110}$, czy też przez utratę urzędu, ekskardynację, albo utratę stałego zamieszkania ${ }^{111}$. Sprawcami przestępstwa uzurpowania władzy spowiednika mogą być zatem zarówno ci, którzy nie przyjęli święceń w stopniu prezbiteratu, a więc diakoni, wierni świeccy oraz zakonnicy bez święceń, jak również sami kapłani w stopniu prezbiteratu, ale nie posiadający wymaganego upoważnienia.

Jak już zostało powiedziane Normy De delictis reservatis z 2010 roku biorą pod uwagę dwie formy przestępstwa uzurpacji władzy spowiednika: usiłowanie rozgrzeszenia sakramentalnego, oraz zakazane słuchanie spowiedzi.

\footnotetext{
103 Por. J. SyryjczyK, Kanoniczne prawo karne..., s. 105-106.

${ }^{104} \mathrm{KPK} / 1983$, kan. 965.

$105 \mathrm{KPK} / 1983$, kan. $966 \S 1$.

106 KPK/1983, kan. 967 § 1.

107 Zob. KPK/1983, kann. 966 § 2; 967 § 1-2; 968; 566 § 1.

108 Zob. KPK/1983, kann. 966 § 2; 969; $967 \S 3$.

109 Zob. KPK/1983, kan. 972.

${ }^{110}$ Zob. KPK/1983, kan. 974 § 1.

111 Zob. KPK/1983, kan. 975.
} 
Pierwsza z form uzurpowania władzy spowiednika, polega na usiłowaniu udzielenia sakramentalnego rozgrzeszenia ${ }^{112}$. Do zaistnienia tej formy przestępstwa wymagane jest, aby sprawca udzielił de facto absolucji z wyznanego przez penitenta przynajmniej jednego grzechu. Tak więc jedynie z chwilą wypowiedzenia słów absolucji sakramentalnej, możemy mówić o dokonaniu tej formy przestępstwa ${ }^{113}$. Autorami tej formy uzurpacji władzy spowiednika mogą być po pierwsze ci, którzy nie przyjęli święceń prezbitaratu. Kto nie przyjął święceń w stopniu prezbiteratu jest niezdolny, na mocy prawa bożego, do udzielenia ważnego rozgrzeszenia. Dlatego też, nie może mieć w takim przypadku zastosowania dyspozycja o kościelnej władzy uzupełniania ${ }^{114}$. Po drugie sprawcami tej formy przestępstwa mogą być także ci ze święceniami, ale bez wymaganego prawem upoważnienia. Brak upoważnienia do spowiadania uniezdalnia prezbitera, z mocy prawa czysto kościelnego, do udzielenie ważnie rozgrzeszenia. Prezbiterzy mogą rozgrzeszać bez wymaganego prawem upoważnienia jedynie w dwóch wyjątkowych sytuacjach. Po pierwsze w przypadku wattpliwości pozytywnej i prawdopodobnej oraz błędu powszechnego, w takich przypadkach Kościół uzupełnia brakującą władzę (kan. 144 § 2). Po drugie - w sytuacji niebezpieczeństwa śmierci penitenta, zgodnie z kan. 976. Jeżeli poza tymi przypadkami, kapłan usiłuje udzielić sakramentalnego rozgrzeszenia popełnia przestępstwo ${ }^{115}$.

Druga z form uzurpowania władzy spowiednika to zakazane słuchanie spowiedzi sakramentalnej bez udzielenia rozgrzeszenia. W tym przypadku mamy do czynienia z sytuacja, kiedy ma miejsce słuchanie spowiedzi sakramentalnej przez osobę, która nie może ważnie udzielić rozgrzeszenia, ale też nie ma takiego zamiaru, penitent jednak musi być przekonany, że przystapił do sakramentalnej spowiedzi ${ }^{116}$. Podob-

112 KPK/1983, kan. 966.

113 Por. J. SyryjczyK, Kanoniczne prawo karne..., s. 105-106.

114 Zob. KPK/1983, kan. 144.

115 Por. A.G. URru, Punire per salvare..., s. 224.

${ }^{116}$ Przestępstwo będzie dokonane nawet jeżeli słuchajacy spowiedzi wyjaśni penitentowi, że nie udziela mu rozgrzeszenia ponieważ nie jest prezbiterem, albo będąc nim nie posiada stosownego upoważnienia, por. J. SYRYJCZYK, Kanoniczne prawo karne..., s. 106. 
nie jak w powyżej omówionym przypadku, także i tutaj sprawcą omawianego przestępstwa może być ten, kto nie posiada święceń w stopniu prezbiteratu, oraz kapłan, który wprawdzie posiada wymaganą władzę święceń, ale brakuje mu stosownego upoważnienia do spowiadania ${ }^{117}$.

\subsection{Symulowanie rozgrzeszenia sakramentalnego}

Kolejne przestępstwo związane z sakramentem pokuty i będące w zakresie kompetencji Kongregacji Nauki Wiary, to symulowanie rozgrzeszenia sakramentalnego ${ }^{118}$. W przypadku tego przestępstwa mamy nawiązanie do kan. 1379 Kodeksu Prawa Kanonicznego z 1983 roku ${ }^{119}$ oraz w kan. 1443 Kodeksu Kanonów Kościołów Wschodnich z 1990 roku $^{120}$. W Normach De gravioribus delictis z 2001 roku brakowało analogicznej dyspozycji. Do zaistnienia przestępstwa w omawianym obecnie przypadku, analogicznie jak w przypadku omówionego wcześniej przestępstwa symulowania liturgicznej czynności Ofiary Eucharystycznej, konieczne są następujące elementy: po pierwsze faktyczne wypowiedzenie formuły rozgrzeszenia; po drugie - brak wymaganej intencji po stronie osoby dokonującej takiej czynności.

Co do pierwszego warunku przestępstwa należy zaznaczyć, że ma zastosowanie to, co zostało powiedziane powyżej odnośnie usiłowania rozgrzeszenia sakramentalnego. Tak więc jedynie z chwilą wypowiedzenia słów absolucji sakramentalnej, możemy mówić o dokonaniu tej formy przestępstwa. Natomiast w odniesieniu do drugiego z warunków, przy uwzględnieniu tego co zostało powiedziane odnośnie symulacji w związku z analizą przestępstwa symulacji czynności liturgicznej Ofiary Eucharystycznej, należy stwierdzić że autorem przestępstwa symulowania rozgrzeszenia sakramentalnego może być zarówno kapłan, jak i ten kto nie posiada święceń w stopniu prezbiteratu, którzy

117 Por. D. CiTo, Delicta graviora..., s. 45.

118 Art. 4: "§ 1, n. 3 simulatio sacramentalis absolutionis de qua in can. 1379 Codicis Iuris Canonici et in can. 1443 Codicis Canonum Ecclesiarum Orientalium”, CongreGATIO PRo Doctrina FIDEI, Normae de delictis Congregationi pro Doctrina Fidei reservatis..., s. 423.

119 KPK/1983, kan. 1379.

${ }^{120}$ KKKW/1990, kan. 1443. 
jednak nie posiadają intencji udzielenia rozgrzeszenia. W sposób zamierzony dokonują wszystkich czynności, jakie składają się na dany znak sakramentalny, wzbudzając w adresatach przekonanie o ważności sakramentu, nie mając jednak, w przypadku kapłana, intencji ważnego udzielenia tego sakramentu, lub nie uzurpując sobie władzy do ważnego rozgrzeszania, w przypadku osoby bez święceń prezbiteratu. Szczególna złośliwość omawianego przestępstwa leży zatem w intencji - zamiarze oszukania w udzielaniu sakramentu rozgrzeszenia. Symulacja bowiem polega na świadomym i dobrowolnym dokonaniu istotnych czynności sakramentu, ale bez wymaganej w danym przypadku intencji dokonania tego sakramentu.

Należy jednak zaznaczyć, że stwierdzenie popełnienia przestępstwa symulowania rozgrzeszenia sakramentalnego w przypadku kapłana będzie napotykało na pewne trudności. Wiąże się to z jednej strony z tym, że Kościół w określonych okolicznościach, uzupełnia brakującą władzę do spowiadania (kan. $144 \S 2$ ), jak i z faktem udzielenia tejże władzy wszystkim kapłanom w przypadku periculum mortis o w czym w kan. 976. W związku z powyższym, jak zauważa jeden z autorów, jedynym przypadkiem podlegającym ewentualnej odpowiedzialności karnej jest sytuacja kapłana, który wiedząc że nie posiada upoważnienia do ważnego rozgrzeszania, wysłuchuje jednak spowiedzi, ale bez wywoływania stanu błędu powszechnego. Chodzi tutaj o kapłana, który nie zwracając uwagi na to iż jest pozbawiony upoważnienia do spowiadania, wysłuchuje spowiedzi i wypowiada formułę sakramentalnego rozgrzeszenia ${ }^{121}$.

2.4. Sollicitatio ad turpia, jeżeli ma na celu grzech z samym spowiednikiem

Następne spośród delicta graviora contra sanctitatem sacramenti Paenitentiae, które zostały zarezerwowane Kongregacji Nauki Wiary to tzw. sollicitatio ad turpia, czyli nakłanianie penitenta do grzechu przeciwko szóstemu przykazaniu Dekalogu w akcie spowiedzi albo z okazji spowiedzi lub pod jej pretekstem, jeżeli ma na celu grzech

${ }^{121}$ D.G. Astigueta, Ultime modifiche al motu proprio..., s. 75. 
z samym spowiednikiem ${ }^{122}$. Przestępstwo to, chociaż w nieco szerszym zakresie, obecne jest zarówno w kan. 1387 Kodeksu Prawa Kanonicznego z 1983 roku $^{123}$, jak i w kan. 1458 Kodeksu Kanonów Kościołów Wschodnich z 1990 roku $^{124}$. Normy De gravioribus delictis z 2001 roku zawierały w tej materii identyczną dyspozycję jak aktualne normy ${ }^{125}$. Do zaistnienia omawianej formy przestępstwa konieczne jest zatem wystąpienie następujących elementów: po pierwsze - namawiane penitenta przez spowiednika do grzechu przeciwko szóstemu przykazaniu Dekalogu, namawianie to musi być ukierunkowane na grzech ze spowiednikiem; po drugie - powyższe namawianie musi mieć miejsce w związku ze sprawowaniem sakramentu spowiedzi.

W odniesieniu do podmiotu czynnego przestępstwa, zarówno Normy De gravioribus delictis z 2001 roku, jak i Normy De delictis reservatis z 2010 roku, używają terminu confessarius, a nie sacerdos, jak to ma miejsce w kan. $1387 \mathrm{KPK} / 1983$. Użycie terminu confessarius wskazuje na fakt, że podmiotem dokonującym przestępstwa może być jakikolwiek spowiednik, a zatem zarówno prezbiter jak i biskup, a nie jedynie prezbiter ${ }^{126}$. Niektórzy autorzy zaznaczają, że to nakłanianie musi wyjść od spowiednika, a nie od penitenta. W tej perspektywie nie konstytuowałaby omawianego przestępstwa sytuacja, kiedy to namawianie wychodziłoby od penitenta, nawet jeśli spowiednik uległby ta-

${ }^{122}$ Art. 4: "§ 1, n. 4 sollicitatio in actu vel occasione vel praetextu confessionis ad peccatum contra sextum Decalogi praeceptum, de qua in can. 1387 Codicis Iuris Canonici et in can. 1458 Codicis Canonum Ecclesiarum Orientalium, si ad peccandum cum ipso confessario dirigitur", Congregatio pro Doctrina Fidei, Normae de delictis Congregationi pro Doctrina Fidei reservatis..., s. 423.

${ }^{123} \mathrm{KPK} / 1983$, kan. 1387.

${ }^{124} \mathrm{KKKW} / 1990$, kan. 1458.

125 Por. Congregatio pro Doctrina Fidei, Epistula..., s. 787. Zob. G. NúÑez, La competencia penal..., s. 378-379; D. BoreK, Ordynariusz a < Delicta Graviora $>$..., s. 119121.

${ }^{126} \mathrm{~W}$ doktrynie dyskutuje się, czy termin sacerdos użyty przez KPK/1983 w kan. 1387 obejmuje również biskupów. Niektórzy autorzy wykluczają taką możliwość, zob. A. Calabrese, Diritto penale..., s. 319. Inni autorzy utrzymują natomiast, że termin sacerdos obejmuje również biskupów. Gdyby biskup dokonał takiego przestępstwa należałoby mówić nawet o okolicznościach obciążających, por. A.G. URru, Punire per salvare..., s. 236-237. 
kim namowom ${ }^{127}$. Wydaje się jednak, że spowiednik, który uległby namowom ze strony penitenta ${ }^{128}$ i następnie sam, słowami bądź gestami, skłaniałby tegoż penitenta do pełnienia grzechu przeciwko szóstemu przykazaniu Dekalogu, dopuściłby się jednak przestępstwa solicytacji ${ }^{129}$. Namawianie może bowiem przybrać różne formy, może polegać na nakłanianiu czy też zachęcaniu, grożeniu, stymulowaniu przy użyciu słów, gestów, pisma ${ }^{130}$. Przestępstwem będzie nakłaniane jedynie do grzechu zewnętrznego ciężkiego przeciwko szóstemu przykazaniu Dekalogu, nie będzie natomiast przestępstwem nakłanianie do grzechu przeciwko dziewiątemu przykazaniu czy pozostałym przykazaniom Dekalogu. Zgodnie z tym co się postanawia w kan. 1387, przestępstwo solicytacji konstytuuje nakłanianie penitenta przez spowiednika do jakiegokolwiek grzechu przeciwko szóstemu przykazaniu, czy to popełnionego samemu z sobą, czy też z inną osobą lub osobami. Cytowany kanon jest faktycznie tak sformułowany, aby umożliwić ukaranie wszelkich możliwych przestępstw związanych z sollicitatio ad turpia. Przykładowo, w myśl kan. 1387, będzie przestępstwem solicytacji doradzanie podczas spowiedzi stosowania środków antykoncepcyjnych niezgodnie z nauką Kościoła, albo też uznawanie za dopuszczalne związki pozamałżeńskie, albo podżeganie do grzechu wewnętrznego u penitenta w postaci myśli, pragnień czy pożądań ${ }^{131}$. Kongregacja z szerokiej gamy możliwych przestępstw z zakresu sollicitatio ad turpia posiada wyłączną kompetencję jedynie w odniesieniu do takiej formy solicytacji, która ma wprawdzie na celu grzech przeciwko szóstemu przykazaniu, ale popełniony z samym spowiednikiem ${ }^{132}$. Dla zaistnienia przestępstwa nie będzie miało znaczenia, czy penitent ulegnie namowom czy też nie, przestępstwo to bowiem polega na samy fakcie

${ }^{127}$ Por. J. SyryJCZYK, Kanoniczne prawo karne..., s. 124.

${ }^{128}$ W sytuacji gdyby nakłanianie wyszło od penitenta, można by się zastanowić nad kwestią odpowiedzialności karnej penitenta na zasadach współudziału w przestępstwie, por. kan. 1329.

${ }^{129}$ V. De Paolis - D. Cito, Le sanzioni nella Chiesa..., s. 342.

${ }^{130}$ Por. tamże, s. 341.

131 Por. J. SyryjCzyK, Kanoniczne prawo karne..., s. 124.

${ }^{132}$ V. De PAolis, Norme de gravioribus delictis..., s. 307-308. 
namawiania ${ }^{133}$. Oczywiście w przypadku zaistnienia innych form przestępstwa solicytacji należy zachować zwyczajną procedurę wymierzania $\operatorname{kar}^{134}$.

Zarówno KPK/1983 w kan. 1387 jak i Normy De gravioribus delictis oraz Normy De delictis reservatis precyzują, że omawiane przestępstwo ma miejsce jedynie wtedy, kiedy sollicitatio jest dokonywana w związku ze sprawowaniem sakramentu spowiedzi, to znaczy in actu confessionis, occassione confessionis praetextu confessionis. Pierwszy przypadek ma miejsce wtedy, gdy sollicitatio dokonuje się w czasie trwania rytu sakramentalnej spowiedzi. Drugi przypadek oznacza, że sollicitatio była dokonana albo zaraz przed spowiedzią, albo zaraz po niej, w tym przypadku może nie dojść wcale do sakramentalnej spowiedzi, ale wymagane jest, aby osoba, która była nakłaniana, miała rzeczywiście zamiar spowiadania się. I w końcu do przestępstwa może dojść również w sytuacji, gdy spowiednik nakłania do grzechu contra sextum pod pretekstem spowiedzi. W tym ostatnim przypadku nie ma wprawdzie intencji sprawowania spowiedzi, ale doprowadza się do spotkania pod pretekstem spowiedzi w celu dokonania solicytacji ${ }^{135}$. Należy zaznaczyć, że nie będzie sprawą łatwą przeprowadzenie procesu mającego na celu wymierzenie kary z tytułu omawianego przestępstwa, szczególnie jeżeli z doniesienia wynika, że solicytacji dokonano $\mathrm{w}$ akcie spowiedzi (in actu confessionis) ${ }^{136}$. Natomiast w przypadku, kiedy zostanie zarzucone kapłanowi nakłanianie przy okazji lub pod pretekstem spowiedzi (occasione vel praetextu confessionis), można postępować zgodnie z ogólnym sposobem postępowania w procesach karnych $^{137}$.

133 Por. J. Syry JCZYK, Kanoniczne prawo karne..., s. 124.

134 Por. D. Ciтo, Delicta graviora..., s. 46.

135 Por. J. SyryjCzyK, Kanoniczne prawo karne..., s. 125-126.

136 Zob. KPK/1983, kan. 1550 § 2, n. 2.

137 Zob. P. BArBero, Tutela della comunione ecclesiale..., s. 210-212. Zob. także G. NúÑEZ, Peculiaridades en la tramitación de las causas de solicitación en el sacramento de la penitencia, Ius Canonicum 40 (2000), s. 627-659. 


\subsection{Bezpośrednia i pośrednia zdrada tajemnicy sakramentalnej}

Przedostanie z przestępstw związanych z sakramentem pokuty i zarezerwowanych Kongregacji Nauki Wiary, wiąże się z nienaruszalnością tajemnicy spowiedzi i polega na bezpośredniej i pośredniej zdradzie tajemnicy sakramentalnej ${ }^{138}$. Nienaruszalność tajemnicy spowiedzi jest chroniona zarówno w Kodeksie Prawa Kanonicznego z 1983 roku $^{139}$ jak w Kodeksie Kanonów Kościołów Wschodnich z 1990 roku $^{140}$. Normy De gravioribus delictis z 2001 roku rezerwowały Kongregacji Nauki Wiary jedynie zdradę bezpośrednią ${ }^{141}$.

Według kan. $983 \S 1$ sigillum sacramentale ${ }^{142}$, czyli tajemnica sakramentalne, jest nienaruszalne, dlatego też nie wolno spowiednikowi słowami lub w jakikolwiek inny sposób i dla jakiejkolwiek przyczyny w czymkolwiek zdradzić penitenta. Spowiednik, na mocy kan. 983, jest zobowiązany do dwóch następujących rzeczy: po pierwsze do zachowania tajemnicy w odniesieniu do grzechów poznanych poprzez spowiedź, i po drugie spoczywa na spowiedniku obowiązek nieużywania wiedzy zdobytej ze spowiedzi, chociaż nie byłoby niebezpieczeństwa rozpowszechnienia tej wiedzy. Powyższe dwa obowiązki nigdy nie dopuszczają wyjątków, tzn. że nie jest możliwe zwolnienie z obowiązku ich zachowywania nawet z powodów najpoważniejszych.

${ }^{138}$ Art. 4: "§ 1, n. 5 violatio directa et indirecta sigilli sacramentalis, de qua in can. $1388 \S 1$ Codicis Iuris Canonici et in can. $1456 \S 1$ Codicis Canonum Ecclesiarum Orientalium", Congregatio Pro Doctrina Fidei, Normae de delictis Congregationi pro Doctrina Fidei reservatis..., s. 423.

${ }^{139} \mathrm{KPK} / 1983$, kan. 1388.

${ }^{140}$ KKKW/1990, kan. 1456.

${ }^{141}$ Por. Congregatio pro Doctrina Fidei, Epistula..., s. 787. Zob. G. NúÑEZ, La competencia penal..., s. 379-380; D. BoreK, Ordynariusz a <elicta Graviora >..., s. 122125.

${ }^{142}$ Doktryna, mówiąc o przedmiocie sigillum, rozróżnia przedmiot istotny i dodatkowy. Przedmiotem istotnym są wszystkie grzechy zarówno penitenta jak i innych poznane ze spowiedzi penitenta, zarówno te śmiertelne jak i lekkie (powszednie); zarówno tajne jak i publiczne, ponieważ ujawnione w celu uzyskania rozgrzeszenia, a zatem znane spowiednikowi na mocy znajomości sakramentalnej. Przedmiot dodatkowy, to z kolei okoliczności towarzyszące grzechom, imię i grzechy ewentualnych wspólników, V. De Paolis - D. Cito, Le sanzioni nella Chiesa..., s. 345. 
A zatem ich naruszenie nie może mieć żadnego usprawiedliwienia, przykładowo w postaci ciężkiej bojaźni, konieczności, czy tym bardziej w postaci poważnej niedogodności ${ }^{143}$. Jest sprawą zrozumiała, że ustawodawca pragnie tutaj chronić jeden z najbardziej świętych i intymnych momentów w życiu chrześcijańskim, to znaczy moment, w którym wierny, zainspirowany łaska, otwiera swoje serce w czasie spowiedzi, aby pojednać się z Bogiem i Kościołem. Ochroną objęte są tutaj także i te sytuacje, kiedy spowiadający się nie spowiadałby się w sposób odpowiedni czy wręcz świętokradczy, na przykład bez żalu lub bez możliwości uzyskania rozgrzeszenia. Także i w takich przypadkach spowiednik jest zobowiązany do zachowania w tajemnicy tego wszystkiego, co usłyszał podczas takiej spowiedzi. Należy jednak podkreślić, że sigillum, o którym mowa stoi na straży nie tylko samego penitenta, jego prawa do prywatności i intymności ${ }^{144}$, ale także sakramentu spowiedzi jako takiego. Dlatego też nawet sam penitent, jako bezpośrednio zainteresowany, nie może zwolnić spowiednika z obowiązku zachowania tajemnicy ${ }^{145}$.

Mając na uwadze dyspozycje zawartą w kan. 1388 KPK/1983 możemy stwierdzić, że przestępstwo naruszenia tajemnicy spowiedzi może przybrać różne formy: może wystapić w postaci bezpośredniej zdrady tajemnicy spowiedzi ze strony spowiednika; może polegać na pośredniej zdradzie tajemnicy spowiedzi przez spowiednika; ponadto przestępstwo może zaistnieć także w przypadku naruszenia tajemnicy przez tłumacza lub jakąś inną osobę. Aktualne Normy De delictis reservatis z 2010 roku dotyczą jedynie naruszenia sigillum sacramentale, a więc zdrady ze strony spowiednika, ale za to w podwójnym jej ujęciu, tj. zdrady bezpośredniej i pośredniej.

${ }^{143}$ Nie będą miały tutaj zastosowania normy zawarte w kann. 1323, n. 4; $1324 \S 1$, n. 5 obowiązującego Kodeksu Prawa Kanonicznego.

${ }^{144}$ Naruszenie tajemnicy spowiedzi stanowi niewątpliwie naruszenie fundamentalnego prawa każdego człowieka do własnej intymności, por. KPK/1983, kan. 220; D. Ciтo, Delicta graviora..., s. 48.

${ }^{145}$ Zob. P. Montini, La tutela penale del sacramento della penitenza..., s. 226-227, przypis nr 42; J. SyryJCZYK, Kanoniczne prawo karne..., s. 130-131. 
Bezpośrednie naruszenie sigillum sacramentale ma miejsce wtedy, gdy spowiednik wyjawia to, co stanowi przedmiot spowiedzi oraz osobę, która popełniła dany grzech, bądź grzechy. Nie jest rzeczą konieczna, aby dany grzesznik był znany przez osobę czy też osoby, wobec których jest wyjawiane sigillum, ale wystarczy, że osoba, która popełniła grzech zostanie oznaczona w sposób wyraźny: np., że burmistrz jakiegoś miasta popełnił taki czy inny grzech. Będziemy mieli do czynienia ze zdradą sigillum również wtedy, kiedy osoba, w stosunku do której się wyjawia grzechy kogoś innego, nie jest świadoma tego, że spowiednik wyjawiający wie to ze spowiedzi. Ponieważ mamy tutaj do czynienia z konieczności z przestępstwem popełnionym $\mathrm{z}$ winy umyślnej ${ }^{146}$, bezpośrednie złamanie sigillum zakłada w kapłanie zdecydowaną wolę przekroczenia przepisu; wymaga się zatem, aby spowiednik był w pełni świadomy tego, że ujawnia to, co usłyszał podczas spowiedzi. Nie będziemy mieli do czynienia z przestępstwem, jeżeli spowiednik wierzy, że wyjawia rzeczy, które poznał gdzie indziej, albo w sytuacji, gdy wyjawienie tajemnicy spowiedzi będzie skutkiem zaniedbania, nieostrożności, a to dlatego, że brakuje tutaj wyraźnej woli łamania przepisu ${ }^{147}$. Jednak w takich przypadkach jest dopuszczalna hipoteza deliktu popełnionego $\mathrm{z}$ winy nieumyślnej ${ }^{148}$. W każdym razie nigdy nie pozostaje przesadnym napominanie, aby unikać opowiadań rzeczy zasłyszanych przy spowiedzi, chociażby nie było żadnego niebezpieczeństwa ujawnienia tajemnicy ${ }^{149}$.

Zdrada pośrednia sigillum sacramentale ma miejsce natomiast wtedy, kiedy wyjawia się albo sam przedmiot spowiedzi bez ujawniania osoby penitenta, albo gdy wyjawia się osobę penitenta, jednak bez wyjawiania jej grzechów, ale w taki sposób, że istnieje możliwość zidentyfikowania osoby penitenta oraz jej grzechów ${ }^{150}$. Z tym rodzajem zła-

\footnotetext{
146 Zob. KPK/1983, kan. 1321 \& 2.

147 Por. P. Montini, La tutela penale del sacramento della penitenza..., s. 227-228.

148 Zob. KPK/1983, kan. 1389 § 2.

${ }^{149}$ V. De Paolis - D. Cito, Le sanzioni nella Chiesa..., s. 346. Konieczność zachowania szczególnej ostrożności w tej materii podkreślił Papież Jan Paweł II w swoim przemówieniu do spowiedników z dnia 12 marca 1994 roku, zob. L'Osservatore Romano, wydanie polskie, 15 (1994) nr 5, s. 21-22.

${ }^{150}$ J. SyRYJCZYK, Ochrona tajemnicy spowiedzi w świetle kanonicznego prawa kar-
} 
mania sigillum mamy do czynienia zazwyczaj wtedy, kiedy spowiednik jest nieostrożny, bez złego zamiaru ${ }^{151}$, lub wtedy kiedy spowiednik jest wypytywany przez innych właśnie w złym zamiarze. Należy jednak podkreślić, że także w przypadku zdrady pośredniej musimy mieć do czynienia z winą umyślna, tzn. że spowiednik musi mieć świadomość tego, że wyjawia to, co usłyszał podczas spowiedzi ${ }^{152}$.

Podmiotem dokonującym omawianego przestępstwa jest spowiednik, a więc kapłan lub biskup, który wyjawia to co usłyszał w trakcie sprawowanego przez niego sakramentu spowiedzi. Nie ma tutaj znaczenia, czy taki spowiednik posiadał upoważnienie do spowiadania czy też nie, gdyż niezależnie od posiadanego upoważnienia jest non zobowiązany do zachowania tajemnicy spowiedzi ${ }^{153}$. Gdybyśmy natomiast mieli do czynienia z osobą nie będącą kapłanem, nie miałoby tutaj miejsca złamanie sigillum we właściwym sensie, ale naruszenie tajemnicy zgodnie z tym, co się mówi w paragrafie drugim kan. 1388, oraz ewentualnie z przestępstwem, o którym mowa w kan. 1378 § , n. $2 \mathrm{KPK} / 1983$.

2.6. Nagrywanie przy pomocy jakiegokolwiek instrumentu technicznego, lub rozpowszechnianie za pomocą środków społecznego przekazu dokonane ze złośliwością, tego co jest mówione przez spowiednika lub penitenta podczas spowiedzi sakramentalnej, prawdziwej lub fałszywej

Ostatnie z przestępstw przeciwko świętości sakramentu pokuty jakie Normy De delictis reservatis z 2010 roku rezerwują Kongregacji

nego, Prawo Kanoniczne 44 (2001) nr 1-2, s. 114-115.

${ }^{151}$ Gdyby jednak spowiednik wyjawił tylko jeden z elementów (penitenta lub jego grzechy), ale z zamiarem wyjawienia obydwu elementów to, jak sie wydaje, dopuściłby sie zdrady bezpośredniej, D.G. Astigueta, Ultime modifiche al motu proprio..., s. 76.

152 Por. P. Montini, La tutela penale del sacramento della penitenza..., s. 227-228.

${ }^{153}$ W sytuacji kapłana pozbawionego upoważnienia do spowiadania, który pomimo tego słucha spowiedzi i następnie dopuszcza się zdrady tajemnicy sakramentalnej spowiedzi mielibyśmy do czynienia z dwoma przestępstwami: z przestępstwem uzurpowania władzy spowiednika w myśl kan. 1378 § 2, n. 2 KPK/1983, oraz z przestępstwem złamania sigillum sacramentale. 
Nauki Wiary, to nagrywanie przy pomocy jakiegokolwiek instrumentu technicznego, lub rozpowszechnianie za pomocą środków społecznego przekazu, dokonane ze złośliwością tego, co jest mówione przez spowiednika lub penitenta podczas spowiedzi sakramentalnej, prawdziwej lub fałszywej ${ }^{154}$. Brakuje analogicznego przestępstwa zarówno w Kodeksie Prawa Kanonicznego z 1983 oraz w Kodeksie Kanonów Kościołów Wschodnich z 1990 roku, jak i w Normach De gravioribus delictis z 2001 roku. Przestępstwo to zostało zdefiniowane w dekrecie Kongregacji Nauki Wiary z 1988 roku. Kongregacja, nawiązując do analogicznego dekretu z 1973 roku, który został uchylony przez wejście w życie KPK z 1983 roku, postanowiła, na mocy upoważnienia udzielonego przez Papieża (por. kan. 30), że: ktokolwiek przy pomocy jakiegokolwiek instrumentu technicznego nagrywa lub rozpowszechnia za pomocą środków społecznego przekazu to, co jest mówione przez spowiednika lub penitenta podczas spowiedzi sakramentalnej prawdziwej lub fałszywej, uczynionej przez niego samego lub przez inne osoby, zaciaga na mocy samego prawa karę ekskomuniki ${ }^{155}$. Przejęcie powyższej dyspozycji w Normach De delictis reservatis z 2010 roku stanowi kolejny dowód na szczególną troskę, z jaką Kościół podchodzi do sakramentu spowiedzi, chroniąc go przed jakimikolwiek nadużyciami.

Omawiane przestępstwo może przybrać trzy różne formy: po pierwsze - może polegać na nagrywaniu spowiedzi; po drugie - może polegać na rozpowszechnianiu spowiedzi; po trzecie - może polegać na nagrywaniu i rozpowszechnianiu spowiedzi. W pierwszym i drugim przypadku chodzi o dwa różne przestępstwa, które mogą być popełnione przez różne osoby. Natomiast w trzecim przypadku mamy do czy-

${ }^{154}$ Art. 4: "§ 2 Firmo praescripto $\S 1$ n. 5, Congregationi pro Doctrina Fidei reservatur quoque delictum gravius quo consistit in captione quovis technico instrumento facta aut in evulgatione communicationis socialis mediis malitiose peracta rerum quae in sacramentali confessione, vera vel ficta, a confessario vel a paenitente dicuntur", Congregatio pro Doctrina Fidei, Normae de delictis Congregationi pro Doctrina Fidei reservatis..., s. 423.

${ }^{155}$ Congregatio pro Doctrina Fidei, decretum, AAS 80 (1988), s. 1367. 
nienia $\mathrm{z}$ jednym przestępstwem, którego autorem jest jedna i ta sama osoba $^{156}$.

Nagrywanie spowiedzi to utrwalanie spowiedzi dokonane za pośrednictwem jakiegokolwiek środka technicznego. Może być ono dokonywane za pośrednictwem magnetofonu lub jakiegoś innego środka służącego do nagrywania na odległość poprzez podsłuch. Należy zaznaczyć, że samo podsłuchiwanie, i to także przy użyciu jakiegokolwiek środka technicznego, które nie jest jednocześnie nagrywaniem, nie będzie przestępstwem o którym mowa. W przypadku samego podsłuchiwania spowiedzi należałoby się odnieść do dyspozycji zawartych w kan. 983, § 2 i ewentualnie w kan. $1388 § 2^{157}$. Elementem charakteryzującym pierwszą formę omawianego przestępstwa jest zatem utrwalanie tego co jest mówione podczas spowiedzi przy użyciu jakiegokolwiek instrumentu technicznego.

Elementem charakterystycznym drugiej formy omawianego przestępstwa jest fakt rozpowszechniania nagranej spowiedzi przy użyciu środków społecznego przekazu. Nie chodzi tutaj zatem jedynie o sam fakt rozpowszechniania tajemnicy spowiedzi (bo to jest rozważane przez kan. $1388 \S 2$ ), ale o raczej o to, że jest to dokonywane poprzez środki społecznego przekazu, to znaczy pisma publiczne, transmisje telewizyjne lub radiowe, Internet itd ${ }^{158}$. Należy zauważyć, iż w ocenie tego przestępstwa trzeba uważnie rozważyć pozycję tzw. wspólników koniecznych (por. kan. 1329 § 2), czyli tych, którzy udzielają swoich usług, aby było możliwe publiczne rozpowszechnienie spowiedzi. Wystarczy tutaj wspomnieć o wydawcach, osobach odpowiedzialnych za transmisje telewizyjne lub radiowe, nawet jeżeli ci wszyscy wspomniani mają na uwadze jedynie cele ekonomiczne lub reklamowe. To już wystarczy, aby uznać ich za uczestników koniecznych i dobrowolnych, a w związku z tym, aby zaciągnęli karę przewidzianą w odniesieniu do głównego autora przestępstwa ${ }^{159}$.

\footnotetext{
${ }^{156}$ Por. D. Ciтo, Delicta graviora..., s. 49.

157 Por. tamże, s. 50.

158 Por. J. SyryjczyK, Kanoniczne prawo karne..., s. 134.

159 Por. D. Ciтo, Delicta graviora..., s. 50.
} 
W przypadku nagrywania i rozpowszechniania spowiedzi mamy do czynienia z jednym przestępstwem, ponieważ jedna jest intencja osoby działającej: nagrywanie spowiedzi jest uczynione w celu jej rozpowszechniania $^{160}$.

Przestępstwa powyżej opisane są popełnione zarówno wtedy, kiedy jest nagrywana i rozpowszechniana spowiedź prawdziwa, jak wtedy, kiedy autor przestępstwa symuluje spowiedź. Może się zdarzyć, że sam spowiednik będzie nagrywał i rozpowszechniał to, co było mówione podczas spowiedzi, po to, aby wskazać na częstotliwość występowania pewnych grzechów na określonym terytorium. Sprawcami mogą być także osoby trzecie, które bez wiedzy penitenta i spowiednika nagrywają lub rozpowszechniają, albo nagrywają i rozpowszechniają to, co było mówione w czasie sakramentalnej spowiedzi. I w końcu może się także zdarzyć, że sprawcą przestępstwa będzie sam penitent, prawdziwy lub fałszywy, popełniający omawiane przestępstwo, głównie w celu rozgłoszenia tego, co zostało powiedziane przez spowiedni$\mathrm{ka}^{161}$.

Ponieważ mamy tutaj do czynienia z przestępstwami popełnionymi na skutek winy umyślnej, za które przewidziana jest kara ekskomuniki latae sententiae, będą zatem konieczne wszystkie elementy odnoszące się przede wszystkim do przypisywalności, aby autor przestępstwa mógł zaciagnąć karę. Nie można, w końcu zapomnieć o tym, iż przestępstwo winno być popełnione przez katolika (por. kan. 11). Karze latae sententiae podlegają nie tylko sprawcy sensu stricto, ale także wszyscy współsprawcy formalni omawianego przestępstwa ${ }^{162}$.

\section{Przestępstwo przeciwko święceniom kapłańskim}

Normy De delictis reservatis z 2010 roku rezerwują Kongregacji Nauki Wiary także delictum gravius attentatae sacrae ordinationis mulieris, a więc przestępstwo polegające na usiłowaniu udzielenia

\footnotetext{
160 Por. tamże.

161 Por. J. SyryjCzyK, Kanoniczne prawo karne..., s. 134.

162 Por. tamże, s. 133.
} 
święceń kapłańskich kobiecie ${ }^{163}$. Brakuje analogicznej dyspozycji zarówno w Kodeksie Prawa Kanonicznego z 1983 roku oraz w Kodeksie Kanonów Kościołów Wschodnich z 1990 roku, jak i w Normach De gravioribus delictis z 2001 roku. Przestępstwo to zostało zdefiniowane przez Kongregację Nauki Wiary dopiero w dekrecie z 2007 roku ${ }^{164}$.

Za omawiane przestępstwo Normy z 2010 roku przewidują karę ekskomuniki latae sententiae zarezerwowaną Stolicy Apostolskiej, oraz, w przypadku duchownego karę fakultatywną wydalenia lub depozycji ${ }^{165}$. Taką samą karę zarezerwowaną Stolicy Apostolskiej przewidziano także w dekrecie Kongregacji Nauki Wiary z 2007 roku.

\subsection{Usiłowanie udzielenia święceń kapłańskich kobiecie}

Omawiane przestępstwo wiąże się ściśle z fundatorem wspólnoty schizmatycznej Morulo Antonio Braschi, który usiłował udzielić święceń kapłańskich kobietom. Kongregacja Nauki Wiary interweniowała w tej sprawie wydając Deklarację Monitum 29 czerwca 2002 roku ${ }^{166}$,

163 Congregatio pro Doctrina Fidei, Normae de delictis Congregationi pro Doctrina Fidei reservatis..., s. 423-424.

${ }^{164}$ Por. Congregatio pro Doctrina Fidei, decretum generale de delicto attentatae sacrae ordinationis mulieris, AAS 100 (2008), s. 403.

165 Art. 5: "n. 1 firmo praescripto can. 1378 Codicis Iuris Canonici, tum qui sacrum ordinem conferre attentaverit tum mulier quae sacrum ordinem recipere attentaverit in excommunicationem latae sententiae Sedi Apostolacae reservatam incurrit” (...) ,3 si vero reus sit clericus dimissione vel depositione puniri peterit", CONGREGATIO PRO Doctrina FIDEI, Normae de delictis Congregationi pro Doctrina Fidei reservatis..., S. 423 .

${ }^{166} \mathrm{~W}$ deklaracji tej, stwierdza się, że udzielone święcenia kapłańskie stanowią symulację sakramentu, i w związku z tym takie święcenia są nieważnie i nieistniejące, i stanowią poważne przestępstwo przeciwko boskiej konstytucji Kościoła. Ponadto mamy tutaj do czynienia z poważnym przestępstwem przeciwko jedności Kościoła, ze względu na fakt, iż biskup wyświęcający należy do wspólnoty schizmatycznej. Jednocześnie, działając zgodnie z kan. 1347 § 1 KPK/1983, Kongregacja upomniała kobiety, które przyjęły święcenia i wezwała do uznania ich nieważności. Niedostosowanie się do tego nakazu, w terminie do 22 lipca 2002 roku, zostało obwarowane karą ekskomuniki (ferendae sententiae) zarezerwowaną Stolicy Apostolskiej, CongREGAZIONE PER la Dottrina della Fede, Dichiarazione (Monitum), L'Osservatore Romano, 11 luglio 2002, s. 6. 
następnie dekret ekskomuniki z 5 sierpnia 2002 roku $^{167}$, oraz dekret z 21 grudnia 2002 roku $^{168}$.

Kongregacja Nauki Wiary, w celu ochrony natury i ważności sakramentu święceń, na mocy specjalnego upoważnienia udzielonego jej przez najwyższą władzę Kościoła (por. kan. 30 KPK/1983), podczas sesji Zwyczajnej z 19 grudnia 2007 roku, zdecydowała, że, z zachowaniem dyspozycji kan. 1378 Kodeksu Prawa Kanonicznego, zarówno ten, kto usiłował udzielenia święceń kobiecie, jak i kobieta, która usiłowała przyjać święcenia, zaciaga karę ekskomuniki latae sententiae, zarezerwowaną Stolicy Apostolskiej. Jeżeli ten, kto usiłował udzielenia święceń kobiecie, albo kobieta, która usiłowała przyjąć święcenia, jest wiernym podlegającym Kodeksowi Kanonów Kościołów Wschodnich, z zachowaniem dyspozycji kan. 1443 tegoż Kodeksu, powinien być ukarany ekskomuniką większą, z której zwolnienie jest zarezerwowane Stolicy Apostolskiej (por. kan. 1423, KKKW/1990). Powyższe dyspozycje weszły w życie w momencie ich publikacji w dzienniku L'Osservatore Romano ${ }^{169}$. Dyspozycje zawarte w cytowanym dekrecie zostały uwzględnione w Normach z 2010 roku, z dodatkiem polegającym na ustanowieniu kary wydalenia lub depozycji dla duchownego.

Przestępstwo usiłowania udzielenia święceń kobiecie to przede wszystkim naruszenie o charakterze doktrynalnym. Takie działanie jest formalnym i uporczywym odrzuceniem doktryny, którą Kościół

${ }^{167}$ Kongregacja Nauki Wiary dekretem z dnia 5 sierpnia 2002 roku wymierzyła karę ekskomunki (ferendae sententiae) zarezerwowanej Stolicy Apostolskiej kobietom, które usiłowały przyjąć święcenia kapłańskie, i które pomimo upomnienia nie uznały nieważności święceń, i nie poprosiły o przebaczenie z powodu powstałego zgorszenia, por. Z. SucheCKI, Le privazioni e le proibizioni..., s. 74.

${ }^{168}$ Kongregacja Nauki Wiary, dekretem z dnia 21 grudnia 2002 roku odrzuciła zarówno prośbę o odwołanie dekretu ekskomuniki z dnia 14 sierpnia 2002 roku, jak i rekurs z dnia 27 września 2002 roku. W powyższym przypadku rekurs nie przysługuje, gdyż Dekret ekskomuniki został wydany przez Dykasterium Stolicy Apostolskiej, które działa w imieniu Papieża (por. kan. 360 KPK/1983). Tym samym Kongregacja potwierdziła dekret ekskomuniki z dnia 5 sierpnia 2002 roku, por. CONGREGAZIONE PER La Dottrina della Fede, Decreto, L'Osservatore Romano, 27-28 gennaio 2003, s. 8.

${ }^{169}$ Congregatio pro Doctrina Fidei, decretum generale de delicto attentatae sacrae ordinationis mulieris, (19 dicembris 2007), AAS 100 (2008), s. 403 . 
nauczał od zawsze, i która została przedstawiona w sposób definitywny przez Papieża Jan Pawła II w 1994 roku w Liście Apostolskim Ordinatio Sacerdotalis w następujący sposób: „Kościół nie ma żadnej władzy udzielania święceń kapłańskich kobietom"170. Zgodnie z powyższym dokumentem to orzeczenie powinno być przez wszystkich wiernych Kościoła uznane za ostateczne. Negowanie tej doktryny, powinno być zatem uznane za odrzucanie prawdy należącej do wiary katolickiej, i w związku z czym pociagga za sobą konieczność zaaplikowania stosownej kary, zgodnie z tym, co się postanawia w kann. 750 § 2 i kan. 1371, n. 1 KPK z 1983 roku $^{171}$. Ponadto, jak zauważa Kongregacja Nauki Wiary w dekrecie z dnia 21 grudnia 2002 roku, osoby które negują powyższą doktrynę utrzymują, że Magisterium Papieskie byłoby wiążące tylko wtedy, kiedy będzie oparte na decyzji Kolegium Biskupów, wsparte przez sensus fidelium, oraz przyjęte przez ważniejszych teologów. Takie jednak postawienie sprawy stanowi negację doktryny dotyczącej Magisterium Papieskiego podtrzymywanej przez Sobór Watykański I i II, i jest jednocześnie nieuznawaniem niereformowalności nauczania Papieskiego dotyczącego doktryny. którą wszyscy wierni mają uznać za ostateczną ${ }^{172}$.

Podmiotami popełniającymi omawiane przestępstwo jest zarówno ten, kto usiłuje udzielić święceń kobiecie, jak i kobieta, bądź kobiety, które usiłują przyjać święcenia ${ }^{173}$. Usiłującymi udzielenia święceń mogą być zarówno duchowni, diakon, prezbiter i biskup, jak i świeccy, mężczyźni lub kobiety. Niezależnie od tego, czy usiłującym udzielenia święceń kobiecie będzie biskup ważnie wyświęcony, czy ktokolwiek inny, święcenia i tak będą tylko usiłowane. Zgodnie bowiem z kan. 1024 KPK/1983 do ważności święceń wymaga się, aby kandydatem był vir baptizatus. Odpowiedzialność karna jest tutaj jednakowa dla

170 JAN PAWEŁ II, List Apostolski Ordinatio sacerdotalis, n. 4, 22 maja 1994, L'Osservatore Romano, 30-31 maj 1994, s. 7-9

${ }^{171}$ Por. JAN PAweE II, List Apostolski motu proprio Ad tuendam fidem, n. 4, L'Osservatore Romano, 18 maj 1998, s. 13-15.

172 Por. Congregazione Per la Dottrina della Fede, Decreto, L'Osservatore Romano, 27-28 gennaio 2003, s. 8. Por. D. Cito, Delicta graviora ..., s. 51-52.

173 Por. D.G. AstiguetA, Ultime modifiche al motu proprio..., s. 79. 
wszystkich współautorów przestępstwa, to znaczy kara ekskomuniki latae sententiae zarezerwowana Stolicy Apostolskiej w przypadku wiernych kościoła łacińskiego, a dla wiernych kościołów katolickich wschodnich kara ekskomuniki większej, także zarezerwowana Stolicy Apostolskiej. Ponadto, gdy sprawcą przestępstwa jest duchowny, przewidziana jest dodatkowa kara ekspiacyjna wydalenia lub depozycji. Surowsza karalność duchownych wskazuje na szczególno szkodliwość wynikającą z postawy duchownego dopuszczającego się omawianego przestępstwa $^{174}$.

\section{Zakończenie}

W niniejszym artykule analizie zostały poddane jedynie te spośród przestępstw zarezerwowanych Kongregacji Nauki Wiary, które dotyczą sakramentów Eucharystii, pokuty i święceń kapłańskich. Normy De delictis reservatis z 2010 roku, w części poświęconej normom substancjalnym, bazuja wprawdzie na tym, co zostało wprowadzone w Normach De gravioribus delictis z 2001 roku, niemniej jednak, w tym co się odnosi do poszczególnych przestępstw przeciwko sakramentom, wprowadzają istotne zmiany i innowacje. Należy stwierdzić, że zarówno zachowanie dotychczasowych dyspozycji w materii delicta graviora, jak i wprowadzenie tutaj pewnych zmian i innowacji wskazuje na to, z jak wielką troską Kościół podchodzi do kwestii ochrony sakramentów. Z drugiej jednak strony, co może być bardzo niepokojące, konieczność aktualizacji norm dotyczących ochrony sakramentów wskazuje na zdarzające się stosunkowo często naruszenia w związku ze sprawowaniem wyżej wspomnianych sakramentów. Przykładowo wprowadzenie do kategorii delicta graviora przestępstwa polegającego na usiłowaniu udzielenia święceń kapłańskich kobiecie było wynikiem konieczności ochrony natury i ważności sakramentu święceń wobec prób podważania stałej nauki Kościoła w materii święceń kapłańskich. W kontekście możliwych naruszeń, w tym co się odnosi do godziwego i/lub ważnego sprawowania sakramentów Eucharystii, pokuty i święceń kapłańskich, istotne znaczenie posiada zatem znajo-

${ }^{174}$ D. Cito, Delicta graviora ..., s. 51. 
mość oraz właściwa wykładnia istotnych znamion przestępstw przeciwko sakramentom, należących do kategorii delicta reservata.

\section{The crimes against the sacraments in the Norms of De delictis reservatis}

\section{from 2010}

Pope John Paul II in the Motu Proprio Sacramentorum sanctitatis tutela on 30 April 2001 promulgated the norms concerning the gravest crimes reserved to the Congregation for the Doctrine of the Faith. Such an intervention of the Church, as the Pope explained, was required by the necessity to protect the sanctity of the sacraments, especially those of the Most Holy Sacrament and Sacrifice of the Eucharist and Sacrament of Penance, as well as the need to keep the purity of morality in regard to the sixth commandment of the Decalogue. The Church, driven by pastoral concern and keeping in mind the ultimate goal of any Church law, which should be salus animarum, intervenes to prevent any violation in such serious and delicate matter as the sacraments. The Congregation for the Doctrine of the Faith issued on 18 May 2001 a letter to the Ordinaries and Hierarchs of the Roman Catholic Church describing the new crimes reserved to the Congregation and the procedural norms to be followed in these cases. Nine years after the promulgation of $D e$ gravioribus delictis norms, the Congregation for the Doctrine of the Faith modified them, integrating and updating them in order to simplify the procedures, so that they could become more effective in solving contemporary problems. The modified norms concerning the crimes reserved to the Congregation for the Doctrine of the Faith were presented to Pope Benedict XVI who approved of them on 21 May 2010 and ordered to promulgate them. De delictis reservatis norms of 2010 consist of two parts: the first one, Normae substantiales, from article 1 to 7 , and the second one including articles 8-31. The first part describes the competence of the Congregation, the crimes belonging to the delicta reservata category, and the norms concerning the prescription of actio criminalis in case of delicta reservata. The latter part defines the procedures in case of delicta reservata for which the Congregation for the Doctrine of the Faith is the Supreme Apostolic Tribunal.

This article analyses only those of the crimes reserved to the Congregation for the Doctrine of the Faith which refer to the sacraments of the Eucharist, Penance and the Priestly Ordinations. It should be stated that both existing and new norms concerning delicta graviora show great concern of the Church for the protection of the sacraments. On the other hand, which seems alarming, the necessity to update the norms protecting the sacraments indicates their relatively frequent violation. For instance, the introduction of an attempt to ordain a woman to the category of delicta graviora was the consequence of the need to protect the nature and significance of priestly ordinations in the times of questioning the Church's teaching in that matter. In the context of possible violations of dignified and valid administration of the sac- 
raments, especially the Eucharist, penance and priestly ordinations, the knowledge and right interpretation of the Church norms promulgated to protect these sacraments seem vital. 